
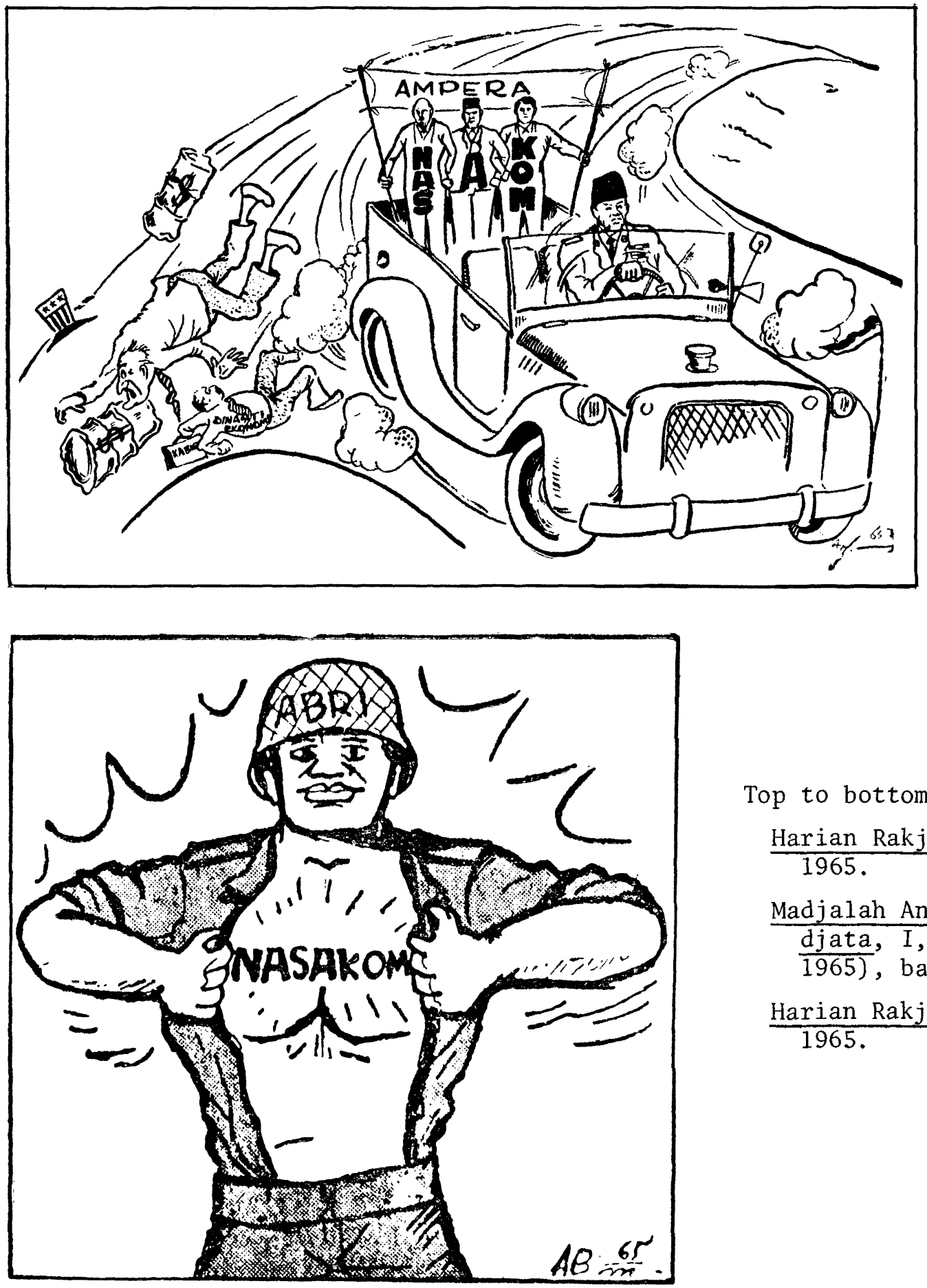

Top to bottom:

Harian Rakjat, April 24, 1965.

Madjalah Angkatan Bersendjata, I, No. 7 (May 1965), back cover.

Harian Rakjat, April 19, 1965.

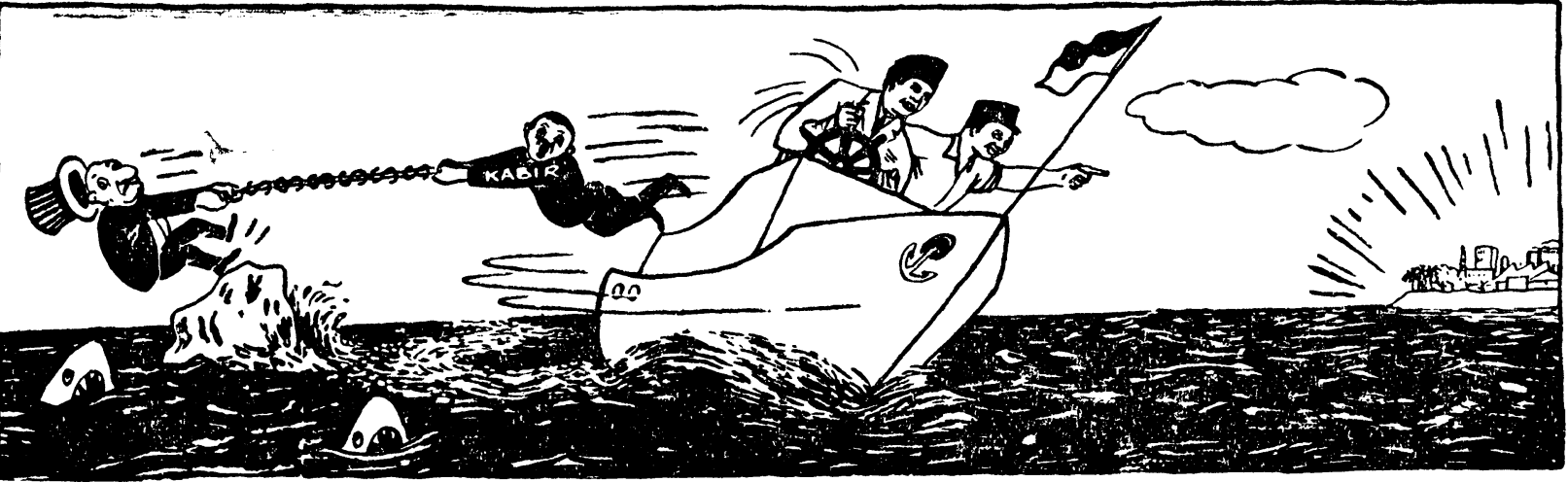




\title{
SUKARNO: RADICAL OR CONSERVATIVE? INDONESIAN POLITICS $1964-5$
}

\author{
Peter Christian Hauswede11
}

The passing of the Orde Lama in Indonesia and the death of President Sukarno seem too recent, and political emotions are still too high to arrive at a definitive characterization of the nature of the political system and its leader. The apparent contradictions between the ideological dynamism and the social conservatism ${ }^{1}$ of Guided Democracy, the lack of conclusive evidence about Sukarno's final political intentions, and the chaotic, even apocalyptic period before the sudden demise of the system all contribute to the difficulty of classification. Finally, the dramatic events around the October 1, 1965 coup attempt have distracted our attention unduly. In Indonesia itself, the political atmosphere does not yet allow an objective assessment of the period. Since nearly all members of the present elite were in one way or another deeply involved in the events of that time, there are few publications about the period, and they have been rather polemical and unsystematic. ${ }^{2}$

Any study which contributes to our knowledge of Sukarno and Indonesian politics before the coup is therefore more than welcome, and John D. Legge's recent political biography of the former President ${ }^{3}$ is the first ambitious attempt to portray this certainly complex, and often contradictory political leader. ${ }^{4}$ Although solid in factual

1. Clifford Geertz used these terms in a different context in his afterword: "The Politics of Meaning" in Claire Holt (ed.), Culture and Politics in Indonesia (Ithaca: Corne11 University Press, 1971), p. 320.

2. See, for example, Pimpinan Redaksi Harian "Merdeka," Tragedi Soekarno (Djakarta: Merdeka Press, 1967); Zainal Abidin Djamaris, Taktik \& Sistem Kekuasaan Dr. Ir. Soekarno (Medan: "IKDI," 1970); and S. M. Amin, Indonesia dibawah Rezim "Demokrasi Terpimpin" (Djakarta: Bulan Bintang, 1967). See also Mochtar Lubis, "Mysticisra in Indonesian Politics," Solidarity (Manila), Vol. XI (November-December 1967), pp. 22-27.

3. J. D. Legge, Sukarno: A Political Biography (London: The Penguin Press, 1972) .

4. The first scholarly attempt to analyze Sukarno's political development till 1945 was Bernhard Dahm's Sukarno and the Struggle for Indonesian Independence (Ithaca: Cornell University Press, 1969). In this essay I will not be concerned with such journalistic studies as, for example, Willard A. Hanna's Eight Nation-Makers (Southeast Asia's Charismatic Statesmen) (New York: St. Martin's Press, 1964), where on pp. 1-92 Sukarno was judged solely in terms of conservative-1iberal Western standards. For an "autobiography" of Sukarno see Cindy Adams, Sukarno: An Autobiography as told to Cindy Adams (Indianapolis: Bobbs-Merri11, $\overline{1965) \text {, and }}$ the later volume My Friend the Dictator (Indianapolis: Bobbs-Merril1, 1967) by the same author. For a particular aspect of politics under Sukarno see Donald E. Weatherbee, Ideology in Indonesia: Sukarno's Indonesian Revolution (New Haven: Yale University, Southeast Asia Studies Monograph Series No. 8, 1966). See also 
material and careful in judgment, the author's interpretation of Sukarno offers no major new departure. Rather he follows the orthodox approach which sees Sukarno as a conservative guardian of the even more conservative-bureaucratic system of Guided Democracy. It will be the argument of this article that in the light of the substantial trend towards the left in Indonesian domestic politics in 1964-5 brought about by a conscious political shift of Sukarno and his strengthened alliance with the Indonesian Left, the late President can no longer safely be seen as a conservative. He should, on the contrary, be seen as a radical during the later period of Guided Democracy, since the political changes set in motion during those final years threatened to undermine the conservative status quo.

In order to focus on the debate on whether Sukarno should be considered a radical or a conservative, this article will only be concerned with Legge's evaluation of Sukarno's political orientation and his characterization of Guided Democracy. It will not attempt to deal with his biography as a whole. Moreover, it is only fair to stress that those arguments I wish to contest are advanced by Legge with a11 the proper reservations of careful judgment. Likewise I want to put forward my interpretation of Sukarno with certain reservations. Although I conclude that Sukarno is better viewed as a radical and that the direction of Guided Democracy was changing, my case will need special argument, for the events of october 1 , 1965, stopped this radical development prematurely; the trend was interrupted before it had brought fundamental changes. The victory of the counterrevolution assured its total repression.

It is expedient to begin by summarizing the arguments which relate to Legge's evaluation of sukarno and the nature of the political system he headed. Although Legge does not specifically refer to the familiar concept which views the Indonesian pre-coup power configuration as a triangle, he implicitly follows it. In his view, Sukarno is essentially balancing, manipulating, and conciliating the opposing forces of the Army and the PKI for the ultimate aim of preserving his own position and power. ${ }^{5}$ Legge's idea of Sukarno as a "balancer" influences him to see domestic politics as a "balancing act"6 and as a "performance."7 This characterization leads him to the image of Sukarno as a dalang, and as a manipulator who in the end tries desperately to keep himself at the top of a constantly shifting power base, and who loses control when he is caught up by his own momentum. ${ }^{8}$

To regard Sukarno as a "balancer" assumes that to the end he is uncommitted, has not really taken sides, and that the triangle with

Justus M. van der Kroef's article, "Sukarno, The Ideologue--A Review Article," Pacific Affairs, Vol. XLI, No. 2 (Summer 1968), pp. 245-261, and the later exchange between Dahm and van der Kroef in Pacific Affairs, Vol. XLII, No. 1 (Spring 1969), pp. 55-57. An Indonesian scholarly treatment is Alfian, "Dasar2 Pemikiran Politik Sukarno," Budaja Djaja, No. 40 (September 1971), pp. 544-560, based on a review of Dahm's Sukarno.

5. See Legge, Sukarno, pp. 9, 378, 381-384.

6. Ibid., p. 381 .

7. Ibid., p. 383.

8. Ibid., pp. 382-383. 
the PKI and the Army is still a working, balanced reality. Such a view of Sukarno leads Legge to see the President's politics primarily from a tactical perspective. Consequently he characterizes Nasakom as a mere tactical device. ${ }^{9}$

Another argument centers upon the outcome of Sukarno's policies. Legge concludes that Sukarno's policies "whether he knew it or not" were protecting the conservative status quo of Guided Democracy and its corrupt elite, 10 and that it is doubtful whether he really wanted a fundamental restructuring of the social order. ${ }^{1}$

In order to solve the apparent contradiction between Sukarno's radical rhetoric and his presumed conservative political objectives, Legge proposes that Sukarno may not have been aware of his motives.i2 This judgment seems to imply that despite an obvious trend to the left in the late Guided Democracy period, its conservative character was not really changing, and that Sukarno's talk of revolution and social change remained abstract and was a tactical device of the balancing act.

Very closely linked to this view of Guided Democracy is the charge that its ideology was a "manipulative device rather than the presentation of a plan of action," "a test of orthodoxy" and "a means of securing conformity." 3 "This overlaps closely with Clifford Geertz' view of ideology as a "smokescreen"14 to conceal reality.

In a general way all these points relate to Sukarno's own view of revolution and social change. Legge asserts that Sukarno understood and talked about revolution mainly for its spiritual and emotional, rather than its practical effects, ${ }^{15}$ and he seems to agree with those who maintain that revolution for Sukarno was "a rhetorical device" and "a temper of mind."16 Legge thinks that he had no clear vision of social change and no revolutionary program. ${ }^{17}$ He states that Sukarno generally followed "vague and abstract goals" rather than "specific and practical ones."18

9. Ibid., p. 348 .

10. Ibid., pp. 8, 353, 383-384.

11. Ibid., pp. 383-384.

12. See Legge's qualifications of "whether he knew it or not" and "whether it was intended to be so or not" (ibid., pp. 384 and 8).

13. Ibid., p. 353.

14. In his "Ideology as a Cultural System" in David E. Apter (ed.), Ideology and Discontent (New York: The Free Press, 1964), p. 70, Geertz described the place of ideology in Indonesian politics as a "smokescreen for failure, a diversion to stave off despair, a mask to conceal reality rather than a portrait to reveal it."

15. Legge, Sukarno, p. 350 .

16. Ibid., p. 8.

17. Ibid., pp. $8,350,383$.

18. Ibid., p. 383; see also p. 353. 
A last major part of Legge's argument concerns Sukarno's relationship with the PKI, which is important for an evaluation of the final period of Guided Democracy. Although he acknowledges that the absence of hard evidence makes it impossible to reach a final conclusion, he argues that Sukarno approved of the PKI's "general temper of thought," but not "of its social programme," 19 that the President was not intending to make the party his heir, ${ }^{\circ}$ and that he was balancing his partnership with the PKI against his partnership with the Army, which he (i.e., Legge) seems to regard as still intact. ${ }^{1}$ Considering whether or not Sukarno's moves of 1964-5 in favor of the Left constitute a conscious pro-PKI policy, Legge thinks that they were a redress of the balance of forces ${ }^{2}$ which had weighed against the PKI, because the Army retained the monopoly of weapons. So he concludes that the PKI in 1965 had not come very much nearer to the "exercise of genuine power," 23 and that, on the contrary, it had lost its "doctrinal purity and its revolutionary will" through' its limited involvement in government and its bid for Presidential protection. ${ }^{24}$

After summarizing Legge's arguments, which are advanced by him with some qualifications, I now want to put forth my rather different interpretation of Sukarno. The gist of my argument is that I tend to see Sukarno no longer as a "balancer," but as one consciously taking sides not only with the PKI, but with all those who were willing to follow his more radical interpretation of the Indonesian Revolution. Therefore I see Nasakom as a means to achieve his desire for a progressive-leftist direction of the revolution, rather than as a mere tactical device to keep himself in power. In fact, if concern for his own position really was his prime motivation, it is inconceivable that he would risk supporting Nasakom despite the formidable resistance it encountered. Sukarno's alliance with the PKI was becoming closer, while his relationship with the Army appeared to be disintegrating and riddled by mutual suspicions. Moreover, Sukarno was no longer in fundamental unity, but rather in growing conflict with the rest of the elite. My interpretation of the later half of Guided Democracy stresses a change of ideological content and a stronger relationship between ideology and political action, which in the end tended to undermine the conservative status quo of the system. Finally, Sukarno's commitment to revolution and social change, although very idiosyncratic and gradual because of the conservative nature of Indonesian power realities, may have been more serious than his orthodox critics would have us believe.

I would stress that Sukarno's domestic politics in 1964-5 were consciously radical in direction much more than would Rex Mortimer. ${ }^{25}$

19. Ibid., p. 353 .

20. Ibid., p. 381 .

21. Ibid.

22. Ibid., p. 378 .

23. Ibid., p. 382 .

24. Ibid., p. 381 .

25. For this and the following quote, see Rex Alfred Mortimer, "The Ideology of the Communist Party of Indonesia under Guided Democracy, 1959-1965" (Ph.D. dissertation, Monash University, 1970), ch. VI, pp. 59-60. 
Mortimer emphasizes, like myself, that the direction of the political process in late Guided Democracy was already undermining the status quo, but, like Legge, he sees in the economic process a conservative aspect of the system. His characterization of the system and Sukarno is therefore focused on the contradiction between conservatism and "political Jacobinism," to both of which Sukarno gave support:

\begin{abstract}
The paradox lies in the fact that, while on the one hand the economic process was gradually cristallising in the emergence of an identifiable stratum of wealthy, politically powerful and conservative politician-bureaucrats, the political process was undermining the security of the incipient new ruling class and increasing the possibility of a radical, communist-1ed attack on their privileges. President Sukarno not only presided over each of these contradictory processes, he gave sustenance to them both. Thus, analyses of the whole system which stress the social conservatism of the elite, and those which emphasise the radical Jacobinism of its leader, both have to be taken into account; the regime was beset by a profound contradiction, mirrored in the personality structure of its President, and the conflicts inherent in this contradiction were, as we shall see, crucial to the crisis that developed in the system in 1965.
\end{abstract}

Before I substantiate my line of argument with more detail, I would like to elaborate on my approach and comment on what I think are some important limitations of the orthodox approach.

A basic weakness of the interpretation of Legge and others ${ }^{26}$ is that they tend to view Guided Democracy as a unified whole, which the events of 1964-5 did not significantly change, or demand a new type of analysis. If a difference between the periods, 1959 to 1ate 1963, and 1964-5 is perceived at all, then it seems that the later period is regarded more as an accentuation in style rather than a change in content. The increase of indoctrination, mass demonstrations, military training, takeover and nationalization of foreign property, etc., are interpreted mostly as an intensification of the ideological "smokescreen" to distract from the increasing political and social contradic-

26. I think here especially of Jan M. Pluvier's work Confrontations: A Study in Indonesian Politics (Kuala Lumpur: Oxford University Press, 1965) which saw the whole system of Guided Democracy as a scheme of Sukarno, the conservative elite and the Army to suppress the PKI (see esp. pp. 52-85, passim). While Legge saw Sukarno as a conservative, Pluvier viewed him more as a reactionary. The point that Guided Democracy was tending to forestall the PKI's rise to power had, of course, already earlier been stressed in Donald Hindley's influential essay "President Sukarno and the Communists: The Politics of Domestication," American Political Science Review, Vol. LVI, No. 4 (December 1962), pp. 915-926; see also his The Communist Party of Indonesia, 1951-1963 (Berkeley: University of California Press, 1966). Both these authors, however, had concluded their studies at a time when the radical trend may not have been so clearly apparent. The only other overall study of Guided Democracy, Herbert Feith's "Dynamics of Guided Democracy" in Ruth McVey (ed.), Indonesia (New Haven: HRAF, 1963), pp. 309-409, was also written too early to perceive the significant changes in the second period. However, Feith's later article "President Soekarno, the Army and the Communists: The Triangle Changes Shape," Asian Survey, Vol. IV, No. 8 (August 1964), pp. 969-980, already registered the new trend. Mortimer's work, "The Ideology," a study of Guided Democracy from his particular research intention, had also indicated a radical trend. 
tions of the system. My interpretation of the years 1964-5 1eads me to the conclusion that the final period of Guided Democracy constitutes a marked departure from the previous one. The case probably does not justify the call for a clearcut "periodization," and any attempt to impose such a framework of periods on the overall analysis of Guided Democracy might hinder an understanding of the essential similarities existing over time. However, we have to account for the radical trend in both domestic and foreign policy which marked Guided Democracy after the "watershed" of late summer 1963, which was dramatically manifested in the change of personalities from Djuanda to Subandrio as Prime Minister. If it is too artificial to argue for a clear break with the previous period, the changes which marked the years 1964-5 from the initial years of the system cannot go unexplained, and I therefore propose to reinterpret them in light of Sukarno's radicalization.

It seems to me that evaluations of Sukarno's political thought and personal characteristics have been rather one-sided. We have become used to regarding his consistency of principles and stubbornness to stick with a once established course as his outstanding personal characteristics. ${ }^{27}$ But in referring to this consistency, we more often pointed to the red thread of anti-colonialism and anti-imperialism, rather than to his consistency as a radical. We took him seriously only as an anti-imperialist. Although social radicalism and anticapitalism were clear in the "early" Sukarno of 1927-33, 28 his political behavior after 1945 seemed to substantiate our doubts about the profundity of his radicalism. The two most conservative, even "rightist" phases of his political 1 ife, in 1948 and in the summer of 1963 , have clearly impaired his radical record and certainly require explanation.

While we all assumed that Sukarno had abandoned any social radicalism for good, we have never seriously considered that he may have merely postponed it. As I will argue later, Sukarno had from the outset--as a tactical expedient--envisaged the postponement of the social revolution to a time when the first stage of the revolution, the national revolution against imperialism, was completed. His domestic radicalism after 1963, when the unified state with the inclusion of West Irian had been established and all domestic rebellions endangering national integration had finally been quelled, is therefore quite consistent with his view of the proper historical sequence of the revolutionary stages, and provides a link to his former phase of radicalism in the late $1920^{\prime} \mathrm{s}$ and early $1930^{\prime} \mathrm{s}$.

Another shortcoming of the orthodox view of Sukarno as a conservative is the tendency to see a fundamental unity between the rest of the elite and him. This analysis stresses that his class background and class privileges made it inherently unlikely that he was interested in profound social changes ${ }^{29}$ undermining the position of the elite, of

27. See Bernhard Dahm, Sukarno, pp. 24, 28, and the late Harry J. Benda's foreword to Dahm, p. vii.

28. For the integration of anti-imperialism and social radicalism in the "early" Sukarno, see his collection of essays Dibawah Bendera Revolusi, I (Djakarta: Panitya Penerbit Dibawah Bendera Revolusi, 1964).

29. See Legge, Sukarno, p. 353; also p. 8. 
which they see him a part. Although history has given ample examples of bourgeois intellectuals and revolutionary leaders negating their class interests in order to take the side of the revolution, orthodox observers do not seem to think that Sukarno could repeat this example.

It seems to me that we have placed Sukarno too much among the elite and too little among the masses. His decided shift to the left in the late period of Guided Democracy represents a conscious shift to a new social reference group. There was a conflict rising between him and the rest of the elite, who wanted to sabotage the leftist interpretation of the revolution. Sukarno seemed intent on cutting the umbilical cord to the "hypocritical" and "reactionary" leaders who used revolutionary vocabulary merely for self-enrichment. He tried to live up to his claim to be a social revolutionist in addition to being an anti-imperialist, and attempted to establish his revolutionaryprogressive credentials and a distinctly new social identity, ${ }^{30}$ which stressed the "people" rather than the elite as his clientele. He no longer appeared interested in an unqualified unity and the security of elite privileges, but rather seemed intent on culling "counterrevolutionaries" from the body politic. ${ }^{31}$

The tendency to doubt Sukarno as a revolutionary stems from certain Liberal-Left Western standards which equate a certain model of personal life-style with the "true" image of a revolutionary. In this context Sukarno's conspicuous consumption and his sexual promiscuity made for some intellectual bankruptcy and did not square well with the criteria for a selfless, devoted and ascetic revolutionary leader, who should possibly wear Castro's army fatigue and sleep on Boumedienne's army cot. Sukarno's vanity was certainly in the way of his radicalism, even to the point of physically diverting his energies and offering a source of distraction. For Western observers some critical contradictions between his private life and his public role existed. They impaired his radical record, but they cannot negate his radical propensities.

Another obstacle to taking Sukarno seriously as a revolutionary leader has generally been his voluntarist and idealist approach to the problem of revolution and social change. He insisted on first instituting a "mental revolution" eliminating colonial inferiority complexes, rebuilding the Indonesian identity, creating a politically and socially conscious revolutionary personality, and engaging in "character building" and "nation building" as well as world-wide opposition to imperialism as a prerequisite to economic development. These aims have been called utterly unrealistic and impracticable. Such charges have some truth in view of Sukarno's disinterest in economic and administrative matters. But given his more radical expectations of the outcome of the revolution, he was certainly correct to charge that the alternative approach of first concentrating on the economy and letting social relations be shaped by the economic base would lead to compromises and disfigurements of the original aims of the revolution.

30. For a change of social identæty, compare Raymond Williams, Orwell (London: Fontana, 1971), pp. 87-88.

31. For Sukarno's criticism of the elite, see his major speeches in 1964 and 1965, especially the Independence Day speeches and the address, as well as the written message, to the MPRS on April 11, 1965, Berdiri Diatas Kaki Sendiri (Berdikari) ([Djakarta]: MPRS dan Departemen Penerangan R.I., Penerbitan Chusus No. 366, [1965]). 
Revolutionary Stages and Sukarno's "Radical Delay"

If one looks for the motives of Sukarno's conscious move to the left in the later half of Guided Democracy, it may be convenient to begin by considering his understanding of revolution and revolutionary stages. Although Legge notes the frequent use of the term "revolution" in Sukarno's last years in office, ${ }^{32}$ he identifies Sukarno's preoccupation with revolution as a spiritual and rhetorical exercise, and doubts his intention and capacity for radical social action.

There is indeed much evidence that the term "revolution," like many others, was used in such an exaggerated and inflationary manner during Guided Democracy that it may well have lost its meaning. It is striking to see how the "Indonesian Revolution," which had been, in essence, a truly heroic independence struggle, but hardly a social revolution in the classical sense, was declared to excel the French and Russian Revolutions and to be the most progressive revolution of the twentieth century, having universal significance. ${ }^{3}{ }^{3}$

Despite the hubris and ideological zeal that these assertions manifested, a case can be made that unlike the rest of the Guided Democracy elite, Sukarno's commitment to and historical understanding of revolution was consistent and reflective. ${ }^{34}$ From the early years of the independence struggle he had conceived of the Indonesian Revolution in two distinct phases, a national and a social phase. ${ }^{35}$ The second phase could only be reached after the first had been completed. The nature of colonial domination dictated the priority of the national revolution against the foreign enemy, for as long as state power was controlled by a foreign colonial power, no social changes could be effected anyhow. The strength of the colonial enemy and the weakness of the Indonesians also required that the social phase of the revolution be postponed, for any social conflict during the national phase

32. Legge, Sukarno, pp. $349 \mathrm{ff}$.

33. For this line of argument, see Sukarno, Reflections on the Indonesian Revolution ([Djakarta]: Department of Foreign Affairs, Republic of Indonesia, 1964), esp. pp. 10-11; Subandrio, The Essence of National Independence and the Revolution of Mankind ([Djakarta]: Department of Foreign Affairs, Republic of Indonesia, [1963]), pp. 11-14. On the universal significance of the Indonesian Revolution, see also the ideological treatises of Ratu Aminah Hidajat, Peranan politik luar negeri Indonesia dan konfrontasi Nefo lawan 01defo, menudju pembentukan dunia Baru ([Bandung?]: n.p., [1964?]), pp. 14-15, and Chaerul Saleh, The Proclamation of 17th of August 1945: The Eruption into Being of the New Emerging Forces (Bandung: Galunggung, [1964?]), pp. 52-55.

34. A rather neglected source on Sukarno's view of revolution, the revolutionary stages, revolutionary leadership, and the subjective and objective factors in a revolutionary situation is his work of 1947, Sarinah (Djakarta: Panitya Penerbit Buku-Buku Karangan Presiden Sukarno, 1963), chapter VI, esp. pp. 254-288. See also his 1958 lectures on Pantja Sila, published in Pantja Sila: The Basis of the State of the Republic of Indonesia ([Djakarta]: National Committee for Commemoration of the Birth of Pantja Sila, [1964]), pp. 83-86.

35. Legge, Sukarno, p. 349, correctly remarked that Sukarno's view of the revolutionary stages may have been influenced by the rather similar Communist terms of a "national-democratic" and a "socialist" phase of the revolution in the colonial countries. For Sukarno's 1ater elaboration of the revolutionary phases, see Sarinah, pp. 264-266. 
of the revolution would have undermined and weakened the unity of the colonized.

While Sukarno's emphasis in the revolution's first stage was antiimperialist, the second stage was anti-capitalist, or at least pointed towards some form of Indonesian socialism. If he did not detail the exact specifications of the social changes he had in mind, this may have been due to a lack of a clear vision of social change, as Legge asserts, but can also be seen as a tactical requirement to keep together the politically and culturally heterogeneous members of his anti-imperialist united front, who would possibly clash in the social phase.

The notion that the revolution consisted of two stages was an important part of Sukarno's political thought, and he consistently argued that the result of the first anti-imperialist stage of the revolution, Indonesian political independence (merdeka), should not be seen as the end of the revolution, but as the bridge to the second stage, the social revolution. The revolution was not yet finished, for the national revolution had just allowed the revolutionaries to seize state power, which now enabled them to effect the social changes necessary to achieve the second objective of the Indonesian Revolution, the just and prosperous society. ${ }^{36}$

If Sukarno was as seriously committed to these ideas and concerned about the progress of the revolution as I have asserted, it can legitimately be asked, why didn't he move to implement his ideas in the $1950^{\prime} \mathrm{s}$ after the nationalists were in control of state power, and what prevented him from doing so after he had gained ascendency in a political system whose rationale supposedly was to carry on the unfinished revolution?

Sukarno's limited political leverage in Indonesian politics from 1945 to roughly $1955--$ which resulted from his collaborationist record and the setting up of a Western-style parliamentary system, where he was confined to the role of an influential, but not all-powerful figurehead President--is not a conclusive explanation of his often conservative and compromising record during this time. More than the limits of his political power restrained sukarno from adopting a more radical program.

A first tentative explanation for the lack of Sukarno's "radical record" in domestic policies during the early 1950's may lie in the fact that in his idealist euphoria about the positive effects of the independence struggle he had probably not understood how rapidly the Indonesian elite would go conservative and how quickly the sacrifice and devotion of the independence struggle would end up in enrichissezvous. Only in the mid-1950's does he seem to wake up to the reality that the elite around him had seen the transfer of sovereignty as the end and the only objective of the revolution and had no intention of entering into an uncertain second social stage of the revolution which might endanger their social privileges and rapidly involve the masses in politics.

36. For the general theme of independence as a "bridge" to the future society, see Sukarno's "Mentjapai Indonesia Merdeka" (1933), in Dibawah Bendera Revolusi, I, pp. 285-289. 
But there are more important reasons for this phenomenon of compromise and "radical delay" in Sukarno. The most profound was that until the return of West Irian, Sukarno was preoccupied with the national stage of the Indonesian revolution and not yet with its social objectives. In this national stage the major priority was the fight against imperialism to achieve the unitary state from Sabang to Merauke, and to safeguard national integration against separatist dangers and internal rebellions.

From the beginning of the 1950's continued Dutch control over West Irian and over the Indonesian economy served to call attention to the unfinished character of the national stage of the revolution, and he rather simplistically, but politically persuasively, attributed all domestic ills to the failure to solve these problems. They demanded priority in the national struggle and generated a postponing of the social objectives of the revolution. The seriousness of the threats to the very survival of Indonesia as a unitary state until 1962 by regional rebellion, and the mixture of warlordism, religious fanaticism and sheer banditry has been underestimated. ${ }^{3} 7$ They preoccupied the concern of the decision-makers, making all domestic social programs impossible.

One can argue that Sukarno's emphasis on the anti-imperialist struggle and his postponement of the social phase of the revolution were not really caused by theoretical concerns about the proper sequence and tactical necessities of the stages of the revolution, but rather reflected a certain personal political hedonism. His antiimperialist political skills were certainly striking when compared with his disinterest and lack of knowledge in administrative, organi zational and economic matters. It can also be argued that the whole foreign policy priority was nothing but a shrewd maneuver, a convenient excuse to ward off domestic social transformations. (See below.) But, after the return of West Irian and the quelling of the domestic rebellion, the unitary state as the objective of the national stage of the revolution was achieved, and there was no longer any need [or any pretext!] to postpone the social phase of the Indonesian Revolution. Nearly all observers see the summer of 1963 as a watershed in Indonesian domestic politics when sukarno for a time was seriously committed to a program of economic stabilization.

The most puzzling aspect of this phase for the argument of sukarno as a radical is, of course, his support for a "rightist," Westernbacked program of economic stabilization. ${ }^{38}$ One cannot explain this

37. For the scope of the domestic challenge to the central authority and its final demise in the early 1960's, see Herbert Feith and Daniel S. Lev, "The End of the Indonesian Rebellion," Pacific Affairs, Vol. XXXVI, No. 1 (Spring 1963), pp. $32-46$.

38. The economic stabilization program worked out by the International Monetary Fund and the United States in cooperation with the Indonesian government basically provided for a credit of $\$ 250$ million (of which the American share would be roughly $\$ 100$ million) to contain the Indonesian inflation and stop the economic decline. Some points on which the IMF insisted as a precondition for the credits were the Indonesian commitments to a reduction of military expenditures, a devaluation of the rupiah, a tight credit policy, a balanced budget, and--most harsh--price decontrol on all commodities. For a discussion of the domestic and international aspects of the stabilization program, see Frederick P. Bunnell, 
period of "inconsistency" by assuming Sukarno was naive about the political concessions these stabilization plans involved to the International Monetary Fund and the USA, although he may have been ignorant about the drastic economic effects these plans would have on the poor. ${ }^{39}$ Sukarno's support of this program and his earlier agreements with the Western oil companies 40 clearly do not fit into a "radical" interpretation and they cannot be ignored.

Sukarno's temporary turn to the right has never been adequately explained. ${ }^{41}$ However, by September 1963 he had largely scrapped the stabilization program after domestic opposition to it had mounted from many quarters, and after he had realized the extent of the domestic and foreign policy concessions entailed. Domestically, the stabilization plans would have committed the Indonesian government to accept certain political and economic demands of its international creditors, which included American insistence on the PKI's exclusion from the cabinet. ${ }^{42}$ Moreover, it became ever more apparent concerning the developing crisis about Malaysia, that the aid to Indonesia would also be made contingent on "reasonable" behavior and restraint towards the new state. ${ }^{43}$ It seems that by September Sukarno was neither willing to accept these foreign policy strings nor to tolerate a capitalist approach to solving Indonesia's economic problems. But the fact remains that for a certain period in 1963 he seems to have been willing to compromise his leftist principles.

A second reason for Sukarno's "radical delay" was his peculiar way of defining the Indonesian revolutionary objectives in the context of an international revolution. He would take detours by supporting international objectives to speed the progress of the domestic revolu-

"The Kennedy Initiatives in Indonesia, 1962-1963" (Ph.D. thesis, Corne11 University, 1969), pp. 308-441, and also Franklin Weinstein, "The Uses of Foreign Policy in Indonesia" (Ph.D. thesis, Cornell University, 1972), pp. 422-423 and 578-582.

39. The so-called "May 26 regulations" of 1963, which were a part of the stabilization program, called among other things for a 400-600\% increase in certain public utility and service costs, which had been heavily government subsidized and kept on an artificially low level before; for details on the May 26 regulations, see J. A. C. Mackie, Problems of the Indonesian Inflation (Ithaca: Cornell Modern Indonesia Project, 1967), pp. 39-40.

40. For an in-depth discussion of the June 1, 1963 agreement with the Western oil companies, where the ties between the U.S. government and the international corporations become strikingly apparent, see Bunnell, "The Kennedy Initiatives," pp. 351-373.

41. For an attempt to explain Sukarno's shift to the right as the interplay of several variables, see ibid., pp. 410-416.

42. See ibid., p. 423. For a very frank admission that the exclusion of the PKI from the government was at all times the major U.S. objective in Indonesia, see the memoirs of the former U.S. ambassador to Indonesia (1958-1965), Howard P. Jones, Indonesia: The Possible Dream (New York: Harcourt Brace Jovanovich, 1971), esp. pp. 236, 254-255, 260 .

43. For a discussion of how the end of the aid program and Indonesia's foreign policy against Malaysia were linked and interpreted in Indonesia, see Weinstein, "The Uses of Foreign Policy," pp. 417-418 and 582. 
tion. His Trotzkyite $v i e w^{4}{ }^{4}$ of the relation between the national and the international revolution was never really taken seriously by his critics. Since they held that such an approach to the domestic revolution was impractical (which it probably was), his foreign policy could easily be called an "adventure." Thereby Indonesian foreign policy could be explained as the ego-trip of an anti-imperialist crusader seeking redress for former colonial sufferings, or as an escapist, "scapegoat" approach of a conservative elite anxiously determined not to rock the boat at home.

The "escapist" and "scapegoat" explanations of Indonesian foreign policy never really dealt with the fact that Sukarno considered the problem of the domestic revolution in its international aspects, and that in his perception there was a very close connection between an anti-imperialist foreign policy and social revolution at home. Since internationally Indonesia was fighting capitalism as the root cause of imperialism, domestic politics would have to be synchronized with foreign policy.

of course, one can argue that Sukarno's international detour was merely a pretext for not doing anything about domestic social progress, and at the same time also a shrewd rationalization for eventual failures, which could always be attributed to the strength of international capitalism and imperialism. But even if Sukarno's foreign policy, for the sake of argument, was just intended to distract from the conservative status quo, these very foreign policy actions had important repercussions on domestic politics, and threatened to undermine the status quo he was supposedly trying to preserve.

Therefore, it seems premature to argue, as Pluvier ${ }^{4} 5$ and Weinstein ${ }^{46}$ have done, that the anti-imperialist foreign policy was basically a diversion, a "safety valve" devised by the conservative elite of Guided Democracy, where the PKI could let off steam without endangering the conservative social status quo. Such a view seems to assume that foreign policy is an isolated and separate area, where anti-imperialist actions would not have domestic political consequences. This

44. Sukarno was well aware of the Stalin-Trotzky debate in the 1920's about the priorities of the international revolution versus "Socialism in one country." See Sukamo, Pantja Sila: The Basis of the State, pp. 137-139, and also Dibawah Bendera Revolusi, I, pp. 521-531. Although Sukarno's name was not mentioned, his "internationalist" foreign policy was also linked to Trotzky by Mohammad Sadli in his contribution to Kebangkitan Semangat 166: Mendjeladjah Tracée Baru (Djakarta: n.p., Simposium, diselenggarakan oleh Universitas Indonesia, 6 Mei 1966-9 Mei 1966 dengan Kerdjasama KAMI dan KASI), various pagings, stenciled.

45. Pluvier, Confrontations, p. 74, asserts that "Confrontation was not meant to annex any Malaysian territory; it was intended only to prevent a social revolution in Indonesia by allowing the PKI to let off steam in a direction where it could do no harm to the Indonesian ruling élite." See also pp. 56-60 for Pluvier's rationale for this interpretation.

46. Weinstein, "The Uses of Foreign Policy," p. 50, writes: "Thus, the anti-Western campaigns of Sukarno not only expressed deeply held feelings but also, among other things, constituted a way in which a basically conservative elite could provide the illusion of revolutionary progress, without undertaking the risks to its own position that a real internal revolution would entail." 
view of the function of Indonesian foreign policy during late Guided Democracy overlooks not only the spillover effects and political consequences foreign policy had on domestic politics, but also the serious ideological and ruinous financial commitment of Sukarno to these policies.

Konfrontasi was probably the most important single cause of the revived dynamism and political offensive of the PKI in 1964-5. The anti-American and anti-British thrust of Indonesia's foreign policy led to the domestic nationalization of foreign capital and property and brought about in the spring of 1965 the plans for an autarchic (berdikari) economy with domestic capital accumulation which in the long run would have denied Indonesia to the international capitalist economy and its domestic allies. The counteralignments towards Confrontation and Indonesian diplomatic collaboration with China under the "PekingDjakarta axis," together with the attempts of the superpowers, especially the U.S., to support anti-Communist, anti-Sukarno groups in Indonesian society, also had the effect of further radicalizing Sukarno and cementing his alliance with the Left.

A third important reason for the slow move of Sukarno towards more radical action, which seems to have contributed to his classification as a "conservative," was the fundamentally conservative power configuration around him. Sukarno's influence was clearly limited by other centers of power in the system. His progressive urge to "move history" forward was not shared by the conservative forces, which contained him and emerged as obstacles to any radical interpretation of the revolution. Despite his popularity and unquestionable authority, in a fundamental sense his power was limited, and he could not risk a head-on struggle with those forces. His awareness of the limitations on his power very much influenced his strategy of gradual political changes to the left, which will be discussed later.

After this enumeration of the objective realities and his peculiar subjective assessments which explain the "radical delay" of Sukarno and his relatively slow radical crystallization, it might be expedient to look at some more immediate personal concerns the President may have felt in the political context of 1964-5. Although other observers have stressed these points before, it seems worth repeating that under the impact of deteriorating health, 47 the President may have felt in those years that his time was running out, and that he had to assure a progressive course of the revolution and leave it in the hands of trustworthy successors.

Sukarno was extremely aware of the judgment of history and anxious to go into the history books as a revolutionary, progressive founding father of the Republic, rather than as the guardian of its conservative and corrupt status quo. He knew that in order to be considered a progressive in historical judgment, his anti-imperialist record was not enough, but had to be complemented by a domestic record of social progress. And he did not want merely to be thought of as a consistent anti-imperialist, but rather as a revolutionary leader. The other Afro-Asian political leaders with whom he linked himself most often, Ho Chi Minh, Nasser, Keita, Nkrumah, Mao Tse-tung and Kim II Sung, and

47. Sukarno had some kj.dney treatment in Vienna in 0ctober 1964; he seems to have suffered from kidney-trouble again in December 1964. He then seems to have been $i l 1$ in August-September 1965. 
others, ${ }^{48}$ had with exceptions and certain contradictions manifested these qualities.

Along with Sukarno's conscious effort to change his social identity and clientele in the last two years of Guided Democracy ${ }^{9}$ there was an increasing predilection to interpret the Indonesian Revolution as a progressive, leftist revolution, and a genuine "people's revolution" in order to differentiate it sharply from a "palace revolution" or a "leaders' revolution." 50 Although this had been the original rationale of Guided Democracy, ${ }^{51}$ the rest of the Indonesian elite had never paid more than 1 ip service to it. Sukarno, however, was seriously committed to living up to these ideological pretensions, and threatened to disengage himself from the reactionary and the hypocritical members of the elite who were unwilling to adjust themselves to the revival of the original radical potential of the Indonesian Revolution. The fate of Ben Bella, a leader who seemed to have had a life style similar to his own, and to whom he had earlier referred as a likeminded revolutionary, seems to have hastened these tendencies in Sukarno. ${ }^{2}$

Given the precarious political stability and the mutual distrust of the major contenders for political power in Indonesia, Sukarno must have become extremely anxious in his last years to set the revolution on a more progressive course, to enforce a political consensus about

48. For a list of leaders with whom Sukarno ranked himself, see his address to the tenth anniversary of the first Asian-African conference, Djakarta, April 18, 1965, After Ten Years Stil1 Onward, Never Retreat! ([Djakarta]: Executive Command Tenth Anniversary First Asian-African Conference, [1965]), p. 11.

49. See above p. 115.

50. See Sukarno's 1964 Independence Day speech, "Tahun vivere pericoloso," especially the "revolutionary laws" he tried to set forward there. For the view of Manipol-USDEK as a "leftist ideology" which has to side with "the majority of the people," see his written message to the first anniversary of Mahadjaja-University: Antara (the English edition is referred to here and in all later references), Dec. 18, 1964, A.

51. For a compilation of the most important documents on the ideology of Guided Democracy, see Bahan-Bahan Pokok Indoktrinasi (Djakarta: Prapantja, 1965), especially the sections on Manipol-USDEK and its specifications. See also ManipolUSDEK in Question and Answer ([Djakarta]: Department of Information, Republic of Indonesia, [1961]).

52. In his 1965 Independence Day speech Tjapailah Bintang-Bintang Dilangit! ([Djakarta]: Departemen Penerangan R.I., Penerbitan Chusus No. 382, [1965]), p. 34, Sukarno said: "There are leaders who are afraid they will meet Ben Bella's fate. They only prove that they are leaders who represent vested interests. Ben Bella's overthrow must serve as a warning to leaders everywhere that as soon as a leader separates himself from the people's interests he will be overthrown." See also p. 21: "The fault of the imperialists and the reactionaries is that they belittle the common people. Some Indonesian leaders, too, feel that they are at the right place only if they are among the wives of high ranking officials, among people of noble ancestry, among bureaucratic capitalist directors, or among landlords or moneylenders. Yes, there are revolutionary leaders and reactionary leaders; there are true leaders and pseudo-leaders." 
it, and to pick a reliable successor. There is indeed a striking similarity to Mao Tse-tung's concern for the preservation of the course of the revolution, the fear of its capture by counterrevolutionary forces, and the attempt to train the correct revolutionary successors.

Sukarno's preoccupation with the figure of Sun Yat-sen may offer some insights into how he $\mathrm{s}$ aw his own role in relation to his successor. ${ }^{53}$ It has already been said that Sukarno aspired to be--1ike Sun Yat-sen--a progressive founding father of the Republic, and whether it was initiated by himself or by others, such a comparison of the two figures was made ${ }^{4}$ during Guided Democracy. It is tempting to see Indonesian succession in terms of the Chinese historical precedent; and moreover there was a remark by the President that he had strong objections to being followed by a Chiang Kai-shek, but wasn't hostile to the possibility of a more leftist representative. ${ }^{5}$

\section{The Alliance with the Left: A Rationale}

I have summarized Sukarno's special personal reasons for gradual acceleration of the domestic revolution, and have attempted to explain which ideological perceptions and domestic and international power realities account for his relatively late revival of radicalism. It

53. In his important speech of 1945, Lahirnja Pantjasila, Sukarno referred repeatedly to Sun Yat-sen's "Three People's Principles" (San Min Chu I) as an important work that led him back from internationalism to nationalism; see The Birth of Pantjasila ([Djakarta: Department of Information, Republic of Indonesia, [1967]), pp. 13, 20. For this see also Bernhard Dahm, Sukarno, pp. 338-339. Sukarno's characterization of Chiang Kai-shek as a reactionary (see the 1965 Independence Day speech, Tjapailah, p. 22) stood in marked contrast to his reference to Sun Yat-sen as the "father of the Chinese nation" (Sukarno's address to the American community in Djakarta, Dec, 21, 1964, in Antara, Dec. 25, 1964, A-B.

54. In a speech before foreign diplomats in Djakarta in 1963, Information Minister Ruslan Abdulgani referred to the parallel between China after 1911 and the present Indonesia, and the parallels between Sun Yat-sen and Sukarno. Abdu1gani told his audience that it would be certain Indonesia would never allow the rise of a Chiang Kai-shek. See the collection of the minister's speeches, Pantjaran Api nan tak kundjung Padam ([Djakarta]: Departemen Penerangan R.I., Penerbitan Chusus No. 292, [1963]), pp. 140-141. I am indebted to Bernhard Dahm for calling this to my attention.

55. According to an interview of Herbert Feith with Ruslan Abdulgani on March 17, 1967 (made available to the author by Ben Anderson), Sukarno called Abdulgani immediately after his speech (see note 54) and asked him jokingly what kind of leader he wanted after he (Sukarno) had left the scene. Abdulgani reportedly replied that he would like a successor embodying the same national, religious and social ingredients which characterized the President. To this Sukarno is said to have replied that since Abdulgani had ruled out the Chiang Kai-shek alternative, would he want a Mao Tse-tung? Abdulgani seems to have answered that this was going too far ("Djangan sampai begitu dong!"), but Sukarno told him to be consistent in terms of his earlier alternative ("kalau begitu kamu kurang konsekwen. Mengapa tidak mau berani terus?"). Hc seemed to have no objection if the PKI won the post-Sukarno competition for national leadership. 
is now expedient to analyze the nature of his relationship to the Left, particularly the PKI, in the late period of Guided Democracy.

In contrast to Legge, I do not see Sukarno as a "balancer" any longer, but believe that he had taken sides. Although one cannot be sure that he intended to make the PKI his heir, he certainly tried to set in motion a political reorientation of the country; the successor would emerge from within the leftist-progressive Nasakom constellation, where the PKI was the best organized and most powerful force.

The Sukarno-Army alliance, which Legge thinks checked the PKI to the very end, actually was gradually disintegrating--riddled by serious mutual suspicions in 1964-5. Fear of an Army coup had driven Sukarno long ago to foster inter-service rivalries and to undermine the institutional loyalties of officers by establishing personal loyalties to him. ${ }^{56}$ By 1965 the combined proselytizing of Sukarno and the PKI--whether it was coordinated or not--had assured the loyalty of Air Force Commander Omar Dhani to the Sukarnoist side, and the political independence of Navy Commander Martadinata was seriously shaken after an internal officers' rebellion. ${ }^{57}$ Only the Army High Command closed its ranks against Sukarno.

The Army was hostile to both domestic political reorientation and Sukarno's China policy, and during the events of 1964 and 1965 it became the organizational and inspirational center of the anti-Communist and anti-Sukarno forces. ${ }^{58}$ It is difficult to argue that the SukarnoArmy alliance against the PKI at that time was still strong, because it is obvious that the Army certainly did not consider Sukarno as its ally, but rather as the chief promoter of the PKI. Sukarno was aware of the trend of army politics, and, moreover, he was too suspicious of its forelyn connections ${ }^{59}$ and the likelihood of a coup with

56. On the general problem of Army-Sukarno relations, see Danie1 S. Lev, "The Political Role of the Army in Indonesia," Pacific Affairs, Vol. XXXVI, No. 4 (Winter 1963-4), pp. 349-364, and Michael Ehrmann, "The Indonesian Military in the Politics of Guided Democracy: 1957-1965" (M.A. thesis, Cornel1 University, 1967).

57. Little is known about the "Progressive Revolutionary Officers' Movement" (Gerakan Perwira Progressif Revolusioner) or about 750 naval officers who paralyzed the Naval Academy in Surabaja by a strike in mıd-February 1965. The strike motives of the rebellious officers were concern about promotions as well as dissatisfaction with corruption in higher ranks. They also demanded Martadinata's resignation. Sukarno's authority seems to have saved Martadinata, but in return he apparently had to soften his earlier anti-Nasakom stand.

58. Although the Army's role in the Badan Pendukung Sukarnoisme (BPS) was concealed from public view, it seems to have provided major financial and logistic support. On the BPS, see below, p. 129, n. 76.

59. Howard P. Jones' memoirs, Indonesia: The Possible Dream, are quite revealing in their frank admission that the United States (1ike the Soviet Union) gave priority in its relations to the Indonesian Army as the guarantee of a future nonCommunist Indonesia; see esp. pp. 127, 147, 203, 312, 345-347. According to Ruth McVey, more than four thousand Indonesian officers received military training in the United States before 1965; see her "The Post-Revolutionary Transformation of the Indonesian Army," Part II, Indonesia, No. 13 (Apri1 1972), p. 169. See this article also generally for the political influence and the military significance of United States-Indonesian Army relations. 
foreign backing, ${ }^{60}$ to trust it as an ally.

Legge, refuting the evidence of a pro-PKI policy of Sukarno in 1965, asserts that Sukarno sided with the Army on the issues of Nasakomization of the armed forces. His repeated refusal to establish a real Nasakom cabinet with PKI shares in the cabinet, is taken as evidence of an unchanged balance of power. However, these moves do not necessarily reflect Sukarno's benevolence towards the Army, but rather signify the limits of his power in face of army resistance. Sukarno's alliance with the Left, especially with the PKI, was the predominant aspect of 1964-5 domestic politics. This alliance, although not always coordinated, and containing sources of potential conflict, set into motion the political orientation to the Left.

Before looking for the evidence of this alliance in the domestic events of that time, an attempt will be made to construct a rationale for Sukarno's alliance with the PKI. I will call my view of Sukarno in those years the "Castro solution" to the problem of the Indonesian Revolution, although a Castro-Sukarno comparison can on $1 y$ be advanced with certain reservations concerning Castro's control over a revolutionary army and the weakness of a compromised Cuban Communist Party.

If, after the return of West Irian and the end of the domestic rebellions, Sukarno was seriously concerned with the problem of social transformation, he had to deal with organizational problems to bring it about and to ensure its correct political direction. For both these reasons, the Indonesian Left, and especially the PKI, gained his personal favor.

Failure to solve problems of organization and social mobilization can be regarded as the central feature of Indonesian politics since independence. The Indonesian Revolution had succeeded in providing its followers with a new political identity, but unlike the genuine social revolutions in neighboring countries (Vietnam, China), it had not served as a tool for revolutionary social mobilization, but indeed had often been used to prevent it, because of the socio-religious conflict such an attempt would have provoked. Social mobilization and

60. In 1964-5 Sukarno was constantly accusing Nekolim of "plotting" and "subversion." He considered the BPS as directed by the CIA (see his speech to the Congress of the Indonesian Journalists' Union [PWI], on Feb. 23, 1965) and asked the military to be aware of subversion (written message to the 19th anniversary of the Siliwangi Corps, in Antara, May 22, 1965, A). The whole "Gilchrist Document" affair seems to have reinforced Sukarno's fear of a linkage between the Army and imperialist powers to overthrow him. This document, purporting to be a letter by the British ambassador Gilchrist to London, in which he referred to "our local army friends," was used by Subandrio in Indonesian diplomacy for the second Afro-Asian Conference to substantiate claims of imperialist subversive intentions against Indonesia. The post-coup military trials of the Army have taken pains to reveal the document as a Communist plot, intended to discredit its relations with Sukarno. According to the Army, the Gilchrist document was a Communist forgery on stationery of the British embassy probably stolen during the ransacking of the embassy in 1963. For the Gilchrist document see Ali Said S.H. and Durmawel Ahmad S.H., Sangkur Adil, Pengupas Fitnah Chianat (Proses Dr. Subandrio didepan Mahmillub) (Djakarta: Ethika, [1967]), pp. 49-53, and G-30-S dihadapan Mahmillub di Djakarta, 3 (djilid I), Perkara Dr. Subandrio (Djakarta: P.T. Pembimbing Masa, [1967]), pp. 73-82. 
discipline are prerequisites for social transformations, and Sukarno, like Castro in 1960, might have looked for an organizational tool to effect these changes. Since the old PNI had not become the Marhaenist cadre party Sukarno had envisaged earlier in the independence struggle, now the PKI, an increasingly radical PNI, and all those who showed revolutionary zeal and willingness to interpret the Indonesian Revolution as a leftist revolution based on a "progressive-revolutionary national unity with Nasakom as its axis," 1 could transmit his radical intentions.

Unlike Legge, who thinks Nasakom was a mere tactic and that Sukarno was not seriously commited to it, ${ }^{2}$ I think it was predominant to the very end. I agree with $\mathrm{Dahm}^{6}{ }^{3}$ that Sukarno in some ways was naive to believe that he could ever unite such diametrically opposed forces as Marxism and Islam. But his belief in its possibility, and $h$ is determination and self-assuredness to enforce such a Nasakom-Consensus before he left the scene must influence our analysis of his actions.

If such a Nasakom unity and consensus ever had become a political reality, the PKI would probably have dominated this national united front because of its superior organization and sheer numbers of followers. This likelihood led many to charge that Nasakom was just a Trojan horse for a PKI ride to power, and that sukarno was either naive on Communism or was becoming a fellow traveler. ${ }^{64}$ I think one can safely deny these charges: in Sukarno's view of the Nasakom make-up, nationalism was certainly the strongest element. Sukarno, unlike others, did not fear the PKI or its role in a Nasakom unity. Others would ask how he dared ride the tiger, and warned him of a Czechoslovakian-type Communist takeover from within, ${ }^{6}$ but Sukarno seemed well assured that he could handle the party and keep it in place. His success in the settling of the Madiun Affair supported his confidence, and to the very end the PKI was probably more dependent on him than he was on the PKI.

It is again interesting to compare Sukarno's relationship to the PKI with Castro's case. If one considers the impact the towering Cuban leader had on the Communist Party of his country, ${ }^{6} 6$ and how his personality created havoc with its doctrinal purity of Marxism-Leninism, it

61. The slogan Persatuan progressip-revolusioner berporos Nasakom was the main slogan of 1965 .

62. Legge, Sukarno, pp. 348-349.

63. Dahm, Sukarno, pp. 64-65, 336-350, explaineu this tendency primarily by Sukarno's strategic eclecticism and his Javanese inclination to look for synthesis and harmony of opposing forces. For Sukarno's stress on unity and synthesis, see also Legge, Sukarno, pp. 9, 71, 340, 356.

64. For an indication that by 1964 this may have been the prevailing view of Sukarno in the U.S. State Department, see Jones, Indonesia, p. 358, see also p. 357.

65. Ibid., p. 236, and pp. 254-255.

66. On the relation between Castro and the Cuban Communist Party, see Andrés Suárez, Cuba, Castroism and Communism, 1959-1966 (Cambridge, Mass.: M.I.T. Press, 1967), and also the special issue on Cuba of Kursbuch (Frankfurt: Suhrkamp), No. 18 (1969), esp. the essay by Hans Magnus Enzensberger, "Bildnis einer Partei-Vorgeschichte, Struktur und Ideologie der PCC," at pp. 192-215. 
is not altogether unthinkable that Sukarno's unquestionable authority and popularity in Indonesia might have achieved the same result with his strong ego and independent-mindedness. It is hard to imagine him as anybody's stooge, and the long record of PKI compromise with the system of Guided Democracy and with his leadership is evidence of his capability to control the party.

However, despite Sukarno's expectations to control the PKI within the envisaged Nasakom unity, the PKI had a different perception of its role in the alliance. Sukarno may have thought that he was initiating and controlling the relationship, but there is evidence that their alliance in 1964-5 was characterized by mutual influences, where the PKI sometimes initiated moves and presented Sukarno with a fait accompli, forcing the government to act. ${ }^{67}$ The anti-imperialist fervor of public politics in the wake of the Confrontation policy had offered the PKI the chance to recapture the political initiative and gain new momentum.

An interesting example of disaccord in the Sukarno-PKI alliance was their disagreement in 1964-5 about the proper definition of Indonesia's revolutionary stages. As we have asserted, there was an increasing eagerness and ambition on Sukarno's side to accelerate the Indonesian Revolution. For example, he remarked several times in 1965 that Indonesia was already entering the "socialist" stage of its revolution. Although Sukarno had earlier elaborated on the two different stages of the Indonesian Revolution, ${ }^{68}$ and had declared that the second stage could only be entered after the first had been completed, in his Berdikari-speech he suddenly explained that Indonesia was now entering its socialist phase. ${ }^{69}$ This zeal was immediately exploited by conservative elements who used it for their own purposes by pointing out that since Indonesia was already in its socialist phase, further changes and reforms were not necessary. $70^{\circ}$

67. The anti-American demonstrations of 1964-5, especially the actions against the Peace Corps, the USIS libraries, American films and finally the seizure of foreign property, although they may have had the tacit support of Sukarno, genera1ly developed a momentum where the government had to interfere in order keep things politically in control. After the actions against foreign property in March and April 1965, all foreign enterprises in Indonesia were finally placed under government control by Presidential Decree No. 6/1965.

68. See the Independence Day speech of 1964, "Tahun vivere pericoloso," and two speeches to the Marhaenist cadre course in Djakarta, March 24-25, 1965, in Ever upward, never go down! ([Djakarta]: - Departemen Penerangan R.I., Penerbitan Chusus No. 365, [1965]).

69. Sukarno, Berdiri Diatas Kaki Sendiri, p. 9.

70. See the editorial in Harian Rakjat, May 6, 1965, and Anwar Sanusi's reference to "signs of misunderstanding" and "abuse" of Sukarno's words in Harian Rakjat, Ju1y $20,21,1965$. The opposition seems to have focused on Sukarno's remarks in the early phase of the independence struggle that Indonesia could attempt a phasensprung in its revolutionary development, i.e., that it could skip the capitalist phase of development and proceed right into socialism. Although Sukarno had later retreated from that statement, his voluntarism let him assert it again in 1964. See his speech of July 6, 1964, Membangun Sosialisme Indonesia dengan konsepsi sendiri! ([Djakarta]: Departemen Penerangan, R.I., Penerbitan Chusus, No. 327, [1964]). These lapses of the President gave the opposition 
The PKI became very concerned about these developments. The party emphasized that the first stage of the revolution was not complete without a thorough implementation of its anti-feudal and anti-imperialist objectives, i.e., the implementation of the land-reform program and the elimination of foreign capital on Indonesian soil. ${ }^{1}$ Although the party was as eager to finish the national-democratic stage and to proceed towards the socialist stage, it objected to having the then dismal state of Indonesian economic and social affairs misleadingly described as "socialism," for it correctly feared a demoralizing effect on its cadres in that case. ${ }^{72}$ Talk of the "socialist" phase of the revolution also immediately touched on the ideological requirement of proletarian leadership, something the PKI had to avoid discussing. These PKI censurings of Sukarno about his theoretical blunders apparent $1 \mathrm{y}$ led him to retreat from his earlier euphoria, and in the Independence Day speech of 1965 he proclaimed that Indonesia was still in the national democratic stage, and would implement the necessary social changes to complete it. 73

The Domestic Power Configuration and the Sukarno-PKI Strategy

As the rationale for Sukarno's alliance with the left has been explained, an analysis of Sukarno's and the PKI's assessment of the domestic balance of power and the political strategy they chose in order to effect the desired changes to the Left will be attempted.

The confused, hectic, and, in retrospect, also apocalyptic domestic atmosphere in Indonesia at that time impairs an attempt to come to an objective assessment of the power realities. Generally accepted indicators of political power seem to be missing. Arguments for an

ample opportunity to stress the possibility of a phasensprung, and the PKI singled out Sajuti Melik as the one spreading this concept (see Harian Rakjat, November 25, 1964).

71. See Aidit's address to the working conference of the Bank Indonesia of June 7, 1965, "Revolusi Indonesia dan Masalah Berdikari," Harian Rakjat, June 9, 1965. For PKI criticisms of Sukarno on the issue of entering the "socialist stage," see also Harian Rakjat, April 29 and May 21, 1965.

72. Compare Mortimer, "The Ideology of the Communist Party," ch. III, p. 45.

73. In his 1965 Independence Day speech Sukarno scolded those countries which called themselves socialist, although they still had imperialist capital in the country and had not even started on national-democratic reforms. He said: "Indonesia does not want to be hypocritical about its socialism. Indonesia clearly states that its revolution is still at the national-democratic stage, although a number of important results havr been achieved at this stage. The time will arrive when Indonesia will build socialism, namely after imperialist capital has been liquidated completely and after the land owned by landlords is redistributed among the people" (see Tjapailah Bintang, pp. 34-35). These firm conditions did not hinder Sukarno from later repeating his earlier ambitious assertion that Indonesia was already entering the socialist stage. He repeated this on Sept. 11,1965 at the installation ceremony of the National Education Council (Antara, Sept. 13, 1965, 4) and 'efore graduates of the Bogor Institute of Agriculture at a ceremony at the Rogor Palace (see Indonesian Herald, Sept. 28, 1965). 
increased weight of the PKI in public politics are generally countered with references to the lack of a Nasakom cabinet, and the preservation of the monopoly of weapons, the ultimate arbiter of conflict, with the Army. The overall impression Legge gives, is that the balance of forces had not really changed, and that Sukarno's moves in favor of the PKI were a "redressing" of the balance of power against the antagonist, who was in sole possession of the means of coercion.

In 1964, Sukarno sided with the PKI on all the major domestic issues. He had outlawed Manikebu, ${ }^{74}$ decided against the anti-PKI proposal for the merger of all parties into one, ${ }^{75}$ supported the acce1erated enforcement of the land-reform programs, outlawed the BPS ${ }^{76}$ and the Murba party, 77 and had the journalists' union purged and BPS newspapers suspended. ${ }^{78}$ The cumulative effect of these moves by January

74. Sukarno banned Manikebu (Manifesto Kebudajaan) in May 1964. It had been formulated by a group of anti-Communist, pro-Western intellectuals 1 ate in 1963 and had advocated universal humanism in cultural works. The PKI had branded its universalism as "national nihilism" and had attacked its l'art pour l'art undertones. For Manikebu, see Keith R. Foulcher, "A Survey of Events Surrounding 'Manikebu', The Struggle for Cultural and Intellectual Freedom in Indonesian Literature," Bijdragen tot de taal-, land- en volkenkunde, 125, 4 (1969), pp. 429-465.

75. Under the disguise of trying to promote the simplification of the party system, the anti-Communist forces in 1964 proposed the dissolution of all political parties and their combination into one. Sukarno rejected this in his 1964 Independence Day speech. For a compilation of the political polemics raging over the domestic iscues of 1964, see the two volumes Polemik H.R. dan Merdeka (Djakarta: Merdeka Press, [1965]) and the PKI publication on the same topic, Polemik Merdeka--Harian Rakjat ([Djakarta]: Harian Rakjat, [1965]).

76. The Badan Pendukung Sukarnoisme (BPS) was a loosely structured platform of antiCommunist newspapers, backed by non-Communist intellectuals and technocrats, the Murba party, Islamic and Christian groups, which had the backing of the Army leadership. Its intention was to separate the ideology of Guided Democracy from Communist influences and to separate Sukarno from the PKI. The movement was thus anti-Communist and also opposed the foreign policy trend, especially the China policy, but it was not--originally--an anti-Sukarno movement. In its major ideological pronouncements, Juti's (Sajuti Melik) articles, "How to Study Sukarnoism," which were printed since June 1964 in the Murba paper Berita Indonesia, major emphasis was placed on drawing a clear line between Sukarno's and all forms of Communist thought. The movement probably started on the assumption that Sukarno could still be "rescued" from what was perceived as a "Communist embrace," and so it attempted to promote Sukarnoism as the sole state ideology at the expense of Communist teachings.

The BPS was officially founded in September 1964 under the leadership of the late Sumantoro, the editor of Berita Indonesia, of B. M. Diah from Merdeka, and Adam Malik, Murba-member and then Minister of Trade. It functioned mainly as a distribution agency for newsprint, and by December 1964 Sajuti Melik's articles were reprinted by about 50 Indonesian newspapers (Antara, Dec. 17, 1964, A). Sukarno banned the movement on Dec. 17, 1964. For the BPS ideology, see Juti (Sajuti Melik), Beladjar Memahami Sukarno-isme, I (Djakarta: n.p., 1964). For the Communist reaction, see "BPS" aksi reaksi (Djakarta: Rakjat, [1965]).

77. The Murba party was temporarily "frozen" on January 6, 1965 and banned for good in September 1965.

78. On February 23, 1965, during a speech commemorating the 19th anniversary of the Indonesian Journalists' Union, Sukarno ordered a temporary ban of all newspapers 
1965 tilted the balance of forces considerably in favor of the PKI. With the major platform of the anti-Communist, anti-Sukarno (and antiChina) forces banned, opposition papers temporarily suspended, the major news agency slowly being "retooled" in favor of the leftists, 79 the Army offered the last guarantee of organized resistance against the Communist offensive and Sukarno's trend to the left.

In 1965 the power realities are more difficult to assess. The aksi sepihak (unilateral action) offensive of the PKI had provoked a strong conservative backlash and had largely put the PKI on the defensive in the countryside of Java and Bali, 80 but the party certainly increased its influence in capital-level politics. On the other hand, the Army's resistance to Aidit's demand to arm the workers and peasants, the formation of a Nasakom cabinet, Nasakomization of the armed forces, and finally, to Sukarno's suggestion of a "Fifth Force," may outwardly substantiate the claim that the PKI offensive had been contained.

It is incorrect, however, to look at these moves of the Army as indications of a basically unchanged balance of power, for they constituted defensive moves, a holding operation, during a time of political offensive by the PKI and Sukarno. In terms of weapons the Army was indeed the strongest force in the country, and the PKI and Sukarno knew this. Their strategy, therefore, was to keep political conflict with their adversaries below the level of physical violence, ${ }^{8}$ so the Army would have no legitimate reason to bring the leverage of its guns to bear on the situation.

Sukarno and the PKI were aware of the strength of the conservative forces, and their strategy was to prevent an open political show-down, which might lead to an armed conflict they were sure to lose. Since Sukarno lacked absolute power, he could not simply decree the desired political changes, for they would have been met by evasion and sabotage. The only strategy open to him was to work for gradual change in the superstructure and to ally himself with the population, in order to effect a political reorientation of the whole system. Sukarno and the PKI seemed to be intent on using both governmental action from the top and mass pressure from below to change the balance of power gradually in their favor. In their strategy the control of the bureaucracy

which had supported the BPS, charging that the movement had been used by the CIA to overthrow him. The Djakarta newspapers banned the next day were:

Berita Indonesia
Berita Indonesia Sport dan Film
Merdeka
Indonesian Observer

$\frac{\frac{\text { Warta Berita }}{\text { Revolusioner }}}{\frac{\text { Garuda }}{\text { Semesta }}}$

Karyawan Gelora Minggu Suluh Minggu

79. In January 1965 Pandu Kartawiguna and Zein Effendi, respectively chairman and member of the Executive Board of Antara, and Murba members with SOKSI connections, were temporarily suspended from their duties.

80. See Jacob Walkin, "The Moslem-Communist Confrontation in East Java," Orbis, Vol. 13, No. 3 (Fall 1969), pp. 822-847, and Mortimer, "The Ideology," ch. VII, pp. 48-49 and ch. VII generally for the PKI's agrarian policy.

81. Compare Ruth T. McVey, "Indonesian Communism and China" in Tang Tsou (ed.), China in Crisis, Vo1. 2: China's Policies in Asia and America's Alternatives (Chicago: The University of Chicago Press, 1968), pp. 382-383. 
and the legal institutions would ultimately be more important than the possession of guns.

Political isolation, rather than outright attack on their adversaries, was therefore the main thrust of the Sukarno-PKI strategy. They intended to erode their opponents' political support, by subverting loyalties, cracking organizational unity, and accentuating inherent contradictions. They emphasized that a clear dividing line had to be drawn between the enemies and the friends of the revolution, 82 and gave the impression that the progress of the revolution was blocked merely by a minority of reactionary "die-hards" and conservatives, who were fighting a losing battle to stem the tide, whereas the great mass of the population wanted to go ahead with it. Unity of the masses under the Nasakom plan had to be forged, the "counterrevolutionary" elements had to be unmasked and cornered, and moral and political pressure had to be brought on them either to "adjust to the rising demands of the revolution" or be left behind. ${ }^{8}{ }^{3}$

Conflict between the "enemies" and the "friends" of the revolution was seen by the PKI as a kind of confrontation. In terms which are strikingly similar to Mao Tse-tung's on the Correct Handling of Contradictions among the People, ${ }^{84}$ the PKI saw the Indonesian situation of 1965 as a contradiction between the "pro-people forces" and the "anti-people forces." The "pro-people forces" were vaguely defined as al1 those who supported Nasakom unity and the progress of the revolution, while the "anti-people forces" specifically in the domestic context were seen as the "capitalist-bureaucrats" (kabir), ${ }_{85}$ the

82. See Sukarno's 1964 Independence Day speech, "Tahun vivere pericoloso," especially the first of his "revolutionary laws" advanced there.

83. See Subandrio's speech on January 5, 1965, Teman jang djadi Kontra-Revolusioner terpaksa kita tinggalkan ([Djakarta]: Departemen Penerangan R.I., Penerbitan Chusus No. 357, [1965]). See also Aidit's remarks at the reception for the 45th anniversary of the PKI on May 26, 1965 in the Aula of the Bank Indonesia, reprinted in Harian Rakjat, May 27, 1965.

84. See Mao Tse-tung, On the Correct Handling of Contradictions among the People (Peking: Foreign Languages Press, 1957). The Indonesian translation of this booklet, Mengurus setjara tepat kontradiksi dikalangan Rakjat, is among the books on Marxism which Njoto in a speech to the political education course of Kotrar recommended as general introductory reading (Harian Rakjat, February 15, 1965).

85. The term "capitalist-bureaucrat" (kabir) was used widely by the PKI in 1965 to single out army members entrenched in economic positions in the state enterprises, and bureaucrats whose jobs allowed for embezzlement and other sources of illegal income. They were together referred to as the dinasti ekonomi. The PKI seems to have borrowed the term from Chinese Communism, where it had been applied to the Chinese big bourgeoisie. This class, interchangeably called "comprador bourgeoisie" and "bureaucrat-capitalist class," was seen as a particular representative of monopoly capital in a semi-feudal, semi-colonial society, having close political and economic ties to state power and foreign imperialism: compare Selected Works of Mao Tse-tung (Peking: Foreign Languages Press, 1961), Vol. IV, pp. 118, n. 167, 367, 398, and Li Wei-han, "The Chinese People's Democratic United Front: Its Special Features," Peking Review, 34 (August 24, 1961), p. 15.

The application of the term "capitalist-bureaucrat" in Indonesia was a bit artificial, since the Indonesian "comprador bourgeoisie" was certainly weak if 
"Trotzkyite groups" (a reference to the Murba party) ${ }^{86}$ and the feudal landlords, together with their foreign imperialist and revisionist backers.87 While the PKI recognized that there were still contradictions among the various members within the Nasakom coalition, it claimed that these were contradictions among the people (kontradiksi2 dikalangan Rakjat), which were non-antagonistic and could be solved through consultation (musjawarah), while the contradictions "between the people and the enemies of the people" (kontradiksiz antara Rakjat dengan musuh2 Rakjat) were antagonistic and had to be solved through confrontation (konfrontasi). ${ }^{8}$ The PKI not only differentiated between "anti-people" and "pro-people" forces in Indonesian society, but also tended to analyze the nature of state power in the non-class terms of a contradiction between a "pro-people aspect" and an "anti-people aspect." 89 "The "pro-people aspect" was represented by Sukarno, other progressives, and governmental agencies who took the side of the people and acted on behalf of the revolutionary demands of the masses, while the "anti-people aspect" was represented by the "counterrevolutionaries" still entrenched in governmental positions. In the PKI estimate of the balance of forces in 1965, the "pro-people aspect" was gaining ascendency over the "anti-people aspect," which was becoming increasingly isolated, because domestic and foreign policy were increasingly shaped by the demands of the masses. 90

compared with that of Kuomintang China. In terms of class analysis it certainly applied better to the Indonesian Chinese capitalists than to the group of Army representatives in economic positions and embezzling bureaucrats, which the PKI wanted to single out. However, not socio-economic analysis but political considerations were responsible for the PKI's use of the term. It intended to highlight the foreign ties of this group with imperialism, and in this context it was certainly accurate. For an important attempt to define the economic and political interests of the capitalist-bureaucrats, where the parallels to the Kuomintang and Chiang Kai-shek's coup of 1927 are repeatedly invoked, see the editorial of Bintang Timur, February 23, 1965.

86. On the PKI view of the Murba party as a "counterrevolutionary," rightist political group, see Harian Rakjat, editorial, January 8, 1965; see also Tesis 45 Tahun PKI (Djakarta: Jajasan Pembaruan, 1965), pp. 12-13. See also note 115 below.

87. The relationship between the domestic "counterrevolutionaries," especially the "capitalist-bureaucrats" and the "Trotzkyite groups," and their foreign backers was stressed repeatedly by the PKI. See for example the New Year's message of the PKI Central Committee in Harian Rakjat, Jan. 1, 1965, "Djadikan 1965 Tahun mengganjang Kapitalis Birokrat dan Melaksanakan Dekon untuk memenangkan Dwikora!" See also Bintang Timur, editorial, Jan. 5, 1965.

88. See Aidit's speech at the reception for the 45th anniversary of the PKI on May 26, 1965 in the Aula of the Bank Indonesia, Harian Rakjat, May 27, 1965; see also Aidit's political report to the Fourth Plenary Session of the PKI Central Committee on May 11, 1965, in Perhebat Ofensif Revolusioner Disegala Bidang!

(Djakarta: Jajasan Pembaruan, 1965), p. 11.

89. On Aidit's development of these concepts, see his The Indonesian Revolution and the Immediate Tasks of the Communist Party of Indonesia (Peking: Foreign Languages Press, 1964), esp. pp. 35-36, 40-43, 80-88, and 124-127. A general assessment of the PKI theory of state power is given in Rex Mortimer, "The Ideology," ch. I1, pp. 82-90.

90. See Tesis 45 Tahun PKI, pp. 15-16 (thesis No. 12), and Aidit, Perhebat Ofensif Revolusioner, pp. 16-17. 
The Turn to the Left: Ideological and Political Changes, 1964-5

It is legitimate to ask whether this PKI evaluation of a changing balance of power in favor of the Left was an example of "positive thinking" and merely a morale boost for party members, or whether it could claim to portray reality. The picture Legge gives is that the power realities had not really changed, while I argue that they had, because conservative positions were seriously undermined.

The change is difficult to perceive in the beginning, because the Sukarno-PKI strategy was one of gradual changes and subversive tactics rather than an open challenge of power. A more radical political trend was initiated by the Left with these changes. They were more clearly felt at the level of capital politics and in the big cities of Java than in the outer islands and in the countryside. By the time of the coup they were still incomplete, and the trend was immediately stopped by the counterrevolution after the coup. But these changes to the left and the potential future social transformations they foreshadowed dominated pre-coup Indonesian politics.

The argument that ideological changes initiated political changes is viewed skeptically by those who follow the orthodox approach that the ideology of Guided Democracy always was a "smokescreen" for essentially conservative status quo politics. However, there was a conscious attempt on the part of Sukarno and the PKI to reinterpret the integrative symbols of the ideology of the Indonesian Revolution in a radical-leftist vein, and to coin new slogans which no longer produced conformity, but induced political change.

In all the preeminent slogans of 1965 the theme stressed was that the Indonesian Revolution should be a "left revolution" (revolusi jang kiri), a "people's revolution." To be progressif-revolusioner was the order of the day. Political cartoons conveyed pictures of the Indonesian state-coach, with Sukarno as the driver supported by the people in Nasakom unity, taking a distinct swerve to the left towards some kind of future Indonesian socialism, the sudden swerve causing counterrevolutionaries and hypocritical elements to fall overboard.91 The ideological slogans which were most prominent reflected this sudden shift of direction and focused on themes the Indonesian Left could fully support, but to which the Right could only pay lip-service.

Formerly, Pantja Sila was the key symbol of the ideology and served as the essence of the special Indonesian identity, but during 1964-5 Sukarno attempted to elevate Nasakom to the same symbolic level as Pantja Sila. ${ }^{92}$ The PKI and Subandrio tried to substitute Nasakom for Pantja Sila as the real identity of the Indonesian Revolution.93

91. Compare the two cartoons in Harian Rakjat, April 19 and 24, 1965.

92. See Sukarno, Berdiri diatas kaki sendiri, p. 8; see a1so Sukarno's address to the Nasakom cadre course on June 1, 1965, Pertjajalah pada benarnja Nasakom! ([Djakarta]: Departemen Penerangan R.I., Penerbitan Chusus No. 373, [1965]).

93. See Subandrio's speech "Revolusi Indonesia Revolusi Nasakom" of February 25, 1965, before a PKI meeting in Medan as printed in Harian Rakjat, March 1, 1965. Subandrio stressed Nasakom as the identity (kepribadian) of the Indonesian Revolution. 
Nasakom was declared a "progressive necessity" of the Indonesian Revolution, and it was characterized by one of the chief ideologues of the system as a more sublime synthesis of all existing political thought in the twentieth century than Marxism had constituted for the nineteenth century (sic!). ${ }^{94}$ Sukarno and the PKI tried to have Nasakom understood not only as a reflection of the reality of a general socialist-communist aliran (socio-cultural "stream") in Indonesian society, but also as making official the PKI's role as this aliran's proper political representative. There were repeated attempts by the antiCommunist forces to convince Sukarno to adopt a Nasamarx (NASionalisme, Agama, MARXisme) or a Nasasos (NASionalisme, Agama, SOSialisme) formu$1 \mathrm{a}$, but he refused such reformulations.95

Legge's view of Nasakom as a political tactic does not correspond to the direction of 1965 politics when Sukarno's Nasakom strategy was still the essential leitmotiv of his political thought. ${ }^{96}$ It is true that Sukarno may have become increasingly aware of the social and political conflicts which would impede realization of Nasakom unity, but to the very end it was his political ideal to try to achieve it.

Because the Nasakom concept was crushed in a bloodbath, skepticism that it was unworkable seems to have been confirmed. However, if one imagines a development of Indonesian politics without the radical changes of the coup, but with the gradual strategy of Sukarno continuing, it is possible that the authority of the President and persistent indoctrination might have succeeded in removing "Kom-phobia" and overcoming the social stigma and political ostracism of the PKI.

The charge that a Nasakom cabinet with PKI representation had not been accomplished and that the PKI therefore had not come any nearer to the exercise of genuine power, is only half true. Rather than relying only on Nasakomization from "the top," the PKI had also started to demand "Nasakomization" from "the bottom." One can argue that the Nasakomized film censorship boards, National Front branches, education commissions, sports teams, etc., did not have any real power. But when they slowly started to permeate all aspects of Indonesian public 1 ife, they set a precedent. And when they influenced the public mass media and Nasakom-indoctrination sessions became a must for ministries and government officials, the institutional positions of the conservatives we re slowly being penetrated. Legislative decrees tried to make Nasakom an accepted fact, a "living reality" in political 1 ife, and forbade anti-Nasakom propaganda. ${ }^{7}$

94. See Ruslan Abdulgani's speech at the occasion of the conferring of an honorary doctorate degree on Sukarno at Padjadjaran University, Bandung, Dec. 23, 1964, in Indonesia, ajam-djantan sedjarah dunia Baru! (Djakarta: Prapantja/Universitas Padjadjaran, [1965?]), p. 38.

95. See Juti [Sajuti Melik], Beladjar memahami Sukarno-isme, pp. 68-71, and his earlier work Pembinaan Djiwa Marhaenisme (Djakarta: Jajasan B.P. "Pantjaka," [1963]), pp. 22-26, for attempts to rephrase Nasakom. For Sukarno's refusal to go along with these anti-PKI moves, see his speech before the PKI anniversary mass-meeting in Senajan on May 23, 1965.

96. Compare Sukarno's speeches before and after the coup in 1965 as reprinted in the Penerbitan Chusus series of the Information Ministry.

97. See MPRS Resolution No. VIII, 1965 in Bahan-Bahan Pokok Indoktrinasi, pp. 12851295 , esp. 1291. 
Besides Nasakom the other two main slogans of the Left were Pantja Azimat Revolusi (The Five Talismans of the Revolution) and Trisakti Tavip (The Three Magic Principles). The first slogan attempted to list Pantja Sila, Nasakom, Manipol-USDEK, Trisakti Tavip and Berdikari (stand on your own feet, i.e., self-reliance) as the five major principles of the Indonesian Revolution. In 1964-5 the conservatives only fully agreed to the first one, because the others had increasingly radical political implications. The other slogan--Trisakti Tavip--referred to sovereignty in politics, economic self-reliance and indigenous cultural identity, which by itself would probably have appealed to all Indonesian nationalists, irrespective of political shading. These three principles, which actually described Indonesia's foreign policy aspirations, would, however, have an immediate anti-conservative impact on Indonesian domestic politics. ${ }^{9}{ }^{8}$

The ideological vocabulary of Sukarno and the PKI became indistinguishable during the final period of Guided Democracy--each influencing the other. This was facilitated by the fact that Njoto was among Sukarno's speechwriters. Although Sukarno basically only pleaded for a "progressive-national unity with Nasakom as its axis," he also made it clear that he considered the workers and peasants to be the pillars of the revolution. ${ }^{9}$ The PKI's slogan of the general line of the Indonesian Revolution at that time, "finish the National Democratic Revolution towards Indonesian Socialism with the National Front, which has Nasakom as its axis, the workers and peasants as its pillars, and Pantjasila as its philosophical basis!"100 finally became one of the official slogans for the celebrations of the 20 th anniversary of the Proclamation of Independence in 1965.101

The greater emphasis given to the Indonesian Revolution as a revolution of and for the masses, and Sukarno's attempt to bridge the gap between the elite and the masses was expressed in an Indonesian equivalent of the Chinese Communist mass line, the gerakan turun kebawah (turba; lit. "to go down," "to go to the lower level").102 The theme that the Indonesian leaders had removed themselves from the masses, were resting on their revolutionary laurels, and had merely an "Impala consciousness" ran like a red thread through Sukarno's speeches in the last two years of Guided Democracy. He was intent on bridging the gap between the elite and the masses by calling for a new, revolutionary, "anti-bureaucratic work style."

98. See below, pp. 140-141.

99. Sukarno, Tjapailah Bintang, p. $23 .$.

100. "Dengan Front Nasional Berporoskan Nasakom, Bersokoguru Buruh dan Tani, Berlandasan idiil Pantja Sila, menjelesaikan Revolusi Nasional Demokratis menudju Sosialisme Indonesia."

101. See the joint instructions of the Minister/Chairman of the Committee to organize the Independence Day festivities and the Leadership Council of the National Front determining the slogans for the 1965 Independence Day, Instruksi Bersama, Menteri/Sekretaris Negara/Ketua Panitya Penjelenggaraan Perajaan Hari Kemerdekaan Indonesia dan Pengurus Besar Front Nasional ([Djakarta]: n.p., [1965]).

102. The Chinese equivalent is hsia fang, i.e., "sending down" or "transfer down." For its importance in Chinese Communism, see Rensselaer W. Lee III, "The Hsia Fang System: Marxism and Modernization," China Quarterly, No. 28 (OctoberDecember 1966), pp. 40-62. 
The idea that a leader should "go down" to the masses and learn from them had much earlier been proclaimed by Sukarno in his admiration for Alexander Herzen and Russian populism, 103 and he may have taken it up again now after a PKI initiative.104 Sukarno called on the Indonesian leaders to leave their offices and learn from the masses, which was the only way to become "a true revolutionary."105 This line squared well with the PKI demand to "integrate oneself with the masses and the revolution," and it naturally had full PKI support. ${ }^{106}$ In the first special turba seminar of the National Front in 1965, the turba work-style was explicitly linked to the issue of social mobilization. ${ }^{107}$ Although the coup interrupted any further plans for turba, in the context of Javanese prijaji politics the very idea of learning from the masses, not to mention actually going down to the masses, already had revolutionary cultural implications.

Still one can ask whether the leftist trend of ideological content and the increasing indoctrination had any real effect on the political process, and whether they were not dealt with by the antiSukarno and anti-PKI forces in the usual way: through double talk, subtle techniques of political sabotage or simple evasion. Although these techniques had guaranteed political survival in the earlier period of Guided Democracy, in the highly charged political atmosphere of 1964-5 they were no longer sufficient. At that time in Indonesia an intense political bipolarization was developing and the pressures on the individual to take sides became very intense. Amidst political confusion and economic chaos, people faced an agonizing choice. As one scholar has remarked: "It became less and less possible to avoid declaring for either Right or Left, and the probable penalty of making a wrong choice grew higher. Alliances and allegiances changed rapidly as people attempted to hedge their political bets."los

In the Indonesia of 1965 the content of political ideology was changing markedly. Because the President supported the Left and legitimized these moves, the country was pressured to follow suit. Even if

103. See Sukarno, Sarinah, pp. 305-306.

104. Compare Aidit's speech to the conference on revolutionary art and literature on Sept. 1, 1964, in Harian Rakjat, Feb. 7, 1965.

105. In a letter of June 10,1965 to the participants of the Nasakom cadre course then going on in the capital, Sukarno wrote that the intention of the turba movement was to "eliminate the bureaucratic spirit (mengikis-habis semangat amtenar), to throw out the leadership style from behind the desk, to become a leader of the people who not only is smart to teach the masses but also smart to searn from the masses." See Harian Rakjat, June 11, 1965. Subandrio later reminded technocrats and specialists that they should stop their "conventional thinking" and carry out a "mental revolution" to carry out turba: see his speech on August 19, 1965 before bank officials, Bank2 di-integrasikan dalam revolusi ([Djakarta]: Bank Negara Indonesia, Bagian Hubungan Masjarakat, [1965]).

106. See Anwar Sanusi's talk before the Nasakom cadre course, June 3, 1965 in Harian Rakjat, June 19, 1965.

107. See Dengan Turba mendjalankan Revolusi-dalam-tjara-bekerdja ([Djakarta]: Front Nasional, Pengurus Besar, 1965).

108. Ruth McVey, "Indonesian Communism and China," p. 377. 
the conservative forces resisted the trend, in public dialogue they had to use the prescribed slogans, if only to use them as double talk. The schizophrenic pressures on individuals increased. One can imagine that if the Sukarno-PKI indoctrination had had more time, more and more people for reasons of sheer opportunism, political protection or plain inertia would have jumped on the bandwagon and "adjusted themselves to the rising demands of the revolution." The new trend of politics slowly permeated all aspects of life. Even the research of the technocrats was determined by the prevailing spirit of the times. ${ }^{109}$ Politics had taken command ("Politik adalah panglima"), and it was necessary to show that one was both "red" and "expert."

The political changes which came in the wake of the ideological reorientation did not immediately result in an open loss of power for the conservatives, but their power was gradually deflated. On the capital level a major attempt was made by Sukarno and the PKI to win control over public opinion and to silence their opponents. The temporary suspension of former BPS newspapers and the slow Nasakomization of the Antara news agency has already been described as a major setback for the conservatives ${ }^{10}$ although it was partially offset by the Army decision to start newspapers on its own or simply to take over former BPS newspapers. ${ }^{11}$ It was a partial help for the Left, when Hsinhua news agency in 1965 emerged as the major supplier of foreign news for Antara and the Indonesian press, putting out lengthy daily mimeographed news bulletins free of charge.

The major new aspect of indoctrination during this period was that in Sukarno's attempt to enforce a Nasakom consensus, the PKI was given official backing and ample opportunity to spread indoctrination on Marxism even to the governmental level. Indoctrination courses and training sessions for ministries and governmental institutions in

109. See for example Subroto and Ali Wardhana, Kerdjasama Ekonomi Antar-NEFOS (Djakarta: Lembaga Penjelidikan Ekonomi dan Masjarakat, Fakultas Ekonomi Universitas Indonesia, 1965); Widjojo Nitisastro et al., Masalah Ekonomi dan Faktor2 Ipolsos (Ideologi, Politik, Sosial) (Djakarta: Leknas, 1965); Selo Sumardjan, Perkembangan politik sebagai penggerak dinamik pembangunan ekonomi ([Djakarta]: Universitas Indonesia, Jajasan Badan Penerbit, [1965]); and Fuad Hassan, Identitas nasional (Djakarta: Departemen Urusan Research Nasional, Madje1is I $\overline{1 m u}$ Pengetahuan Indonesia, Lembaga Ekonomi dan Kemasjarakatan Nasional, 1965). For the effect of Communist analytical terms and Sukarno's vocabulary on the military, see for example Major-General S. Sokowati, Amalkan Tri-Ubaya-Cakti ([Djakarta?] : Staf Umum Angkatan Darat-5, [1965]), where world politics is analyzed in terms of Communist contradictions theory (especially p. 23). For the use of Communist contradictions theory in military publications, see also Doktrin Perdjuangan TNI "Tri Ubaya Cakti" (Results of the Army Seminar, April 2-9, 1965, in the Army Staff and Command School, Bandung) ([Djakarta]: Pengurus Besar Front Nasional, Bagian Indoprop, No. 04, [1965]) and the National Defense Institute study by Air Marshal Suharnoiso Harbani, Vichaksana Yudha, Pandangan Positip tentang pemutusan Garis Hidup Imperialisme ([Djakarta]: Lembaga Pertahanan Nasional [July 1965]), stenciled.

110. See above, notes 78 and 79 .

111. When the Murba paper Berita Indonesia was closed down, the Army simply took over the editorial staff and the publishing facilities and ran it as an Army newspaper under the name of Berita Yudha. The Army paper Angkatan Bersendjata started publication on March 15, 1965. 
Djakarta contained standard lectures on Marxism, and they complemented the PKI's earlier policy to address the police and the armed forces on the subject. ${ }^{112}$ The attempt to make Marxism accepted officially as a central part of the ideology of the Indonesian Revolution was, of course, resisted, but it is questionable to what extent the conservatives could have finally resisted a trend which was legitimized by Sukarno's backing and which slowly made inroads on the institutions of public opinion and education.113

The pressures to adjust to the "revolutionary crystallization" and the "rising demands of the revolution" were also felt by the remaining Indonesian parties. Although one cannot call it a gleichschaltung, ideological and political pressures were brought to bear to "retooi"114 personnel and adjust their programs. The Murba party was finally banned in September 1965. Although the party was insignificant in terms of members, it was an important enemy of the PKI because of its elite composition, its share of "capitalist-bureaucrats," its Army connections, and especially its relations to "modern revisionism."115 As

112. See D. N. Aidit, PKI dan Angkatan Darat (SESKOAD) (Djakarta: Jajasan "Pembaruan," 1963) and Angkatan Bersendjata dan Penjesuaian Kekuasaan Negara dengan Tugas2 Revolusi (PKI dan Angkatan Darat SESKOAD) II (Djakarta: Jajasan "Pembaruan," 1964); PKI dan ALRI (SESKOAL) (Djakarta: Jajasan "Pembaruan," 1963) and Marxisme dan Pembinaan Nasion Indonesia (PKI dan ALRI) II (Djakarta: Jajasan "Pembaruan," 1965); PKI dan AURI (Djakarta: Jajasan "Pembaruan," 1963) and Revolusi, Angkatan Bersendjata \& Partai Komunis (PKI dan AURI) II (Djakarta: Jajasan "Pembaruan," 1964); PKI dan Polisi (Djakarta: Jajasan "Pembaruan," 1963).

113. Aidit and Njoto, for example, were appointed as professors of Marxism in the newly founded National Defense Institute (Lembaga Pertahanan Negara). See Ampera Review, Vol. 2, No. 5 (May 1965), p. 24; Antara, May 7, 1965, B. In the field of education Ruslan Abdulgani's instruction for the inclusion of Marxism as one of the basic subjects in all the faculties of the Teacher's Training Institute (IKIP) in Bandung could have set a precedent, see Antara, March 6 , May 17, 1965, B. In the official slogans for the 20th anniversary of the Proclamation of Independence, Marxism was hailed as "a science competent to solve political, social and historical problems." See Instruksi Bersama cited at note 101 above.

114. Sukarno's use of the word "retool" seems to be a mere euphemism for "purge." For the attempt at a definition see Presidential Decision No. 240/1964 on the duties and organization of the new "High Command for the Retooling of the Instruments of the Revolution" (Komando Tertinggi Retooling Alat Revolusi) in Himpunan2 Keputusan Penting mengenai Komando Textinggi Retooling Alat Revolusi (Djakarta: Kotrar, Penerbitan Chusus No. 2, 1964), p. 8: "'Retooling' adalah pembongkaran susunan peralatan jang tidak effisien, dengan pengertian susunan peralatan jang baru."

115. In the context of Sukarno's foreign policy cooperation with China, which the PKI backed and which the Soviet Union wanted to contain, the Murba party's proSoviet line became especially dangerous to the PKI because it could have encouraged a dissenting pro-Moscow group in the PKI itself. In 1964-5 Moscow was increasingly losing its influence on the PKI and seems to have looked to the Murba party (and former PSI elements) to gain leverage on the Indonesian scene. Murba's strength did not lie in its membership figures, but in its elite representation. The Soviets had good ties to Adam Malik (former ambassador to Moscow, 1960-1963) and probably also to Sukarni Kartodiwirjo, the Murba 
another observer has pointed out, ${ }^{116}$ changes within the PNI at that time also reflected genuine leftist pressures especially from the youth organization and the small radical wing of a party which hitherto could have been safely labeled as conservative-bureaucratic. There were also minor leadership changes in Perti, Partindo and IPKI in favor of the leftists.127 Only the NU, one of the Nasakom parties, seems to have avoided internal interference.

Sukarno's emphasis on the Indonesian Revolution as a "people's revolution," the increasing mass demonstrations against selected groups like the "capitalist-bureaucrats" (kabir) and individual ministers (Adam Malik, Chaerul Saleh), and demands to purge the governmental structure from "counterrevolutionary elements" created a political atmosphere where the government came under increasing public pressure and scrutiny. This public pressure on the conservative strongholds of the government was primarily manifested in street demonstrations, petitions, and boycott actions led by the PKI, which now demanded governmental performance in accordance with the new radical ideology. The area where this PKI-led mass pressure became most apparent was in the judicial system.

The idea of an independent judiciary in Indonesia slowly eroded during that time, making way for a new concept of "revolutionary" justice." This movement had origins in Sukarno's and Aidit's ${ }^{118}$ reminder to the 1 aw-enforcing police "to side with the people" and to eliminate "people-phobia." It is also evident that Aidit thought that some Indonesian laws had already become obsolete in the present revolutionary situation and that new "progressive" criteria had to be found

chairman, whose two children were studying in Moscow. Both Malik and Sukarni were important members of the Angkatan 145 and Malik was close to the President. The PKI leadership was not only concerned about Moscow's support of Murba, but also about Murba's good relations with the Army and the Army union federation, SOKSI. This Army support of Murba materialized after the ban on the BPS, when many Murba members got Army protection and employment. In June 1965 some Murba elements started a secret newsbulletin with the title Observation, which was stenciled and apparently distributed among former members. The political analyses in Observation were primarily anti-Peking and anti-PKI, and praised the Soviet domestic and foreign policy line: see reprint from Observation in the stenciled Army intelligence bulletin Laporan Situasi, No. 004/CLS/1965 [Djakarta] .

116. See J. Eliseo Rocamora, "The Partai Nasional Indonesia, 1963-1965," Indonesia, No. 10 (October 1970), pp. 143-181.

117. In Perti, H. Rusli was replaced as chairman by K. H. Siradjuddin Abbas; in Partindo, Asmara Hadi had Sukarno's support over the Dr. Buntaran-Winarno group from Bandung; in IPKI, the anti-Communist chairman Sugirman was replaced by the (salon-) radical Mrs. H. Aminah Hidajat at the IPKI plenary session in Lembang (May 20-25, 1965). She was, however, still balanced by the three "rightist" vice-chairmen, Drs. Achmad Sukendro, Achmad Sukarmidjaja and Sadikin as well as by secretary-general Dr. Sutopo. For the programs of these smaller parties, see Almanak Lembaga2 Negara dan Kepartaian ([Djakarta]: Departemen Penerangan, Republik Indonesia, [1961]).

118. See Sukarno's address to the all-Indonesia police commanders' working conference, August 31, 1965, in Antara, Sept. 2, 1965, A; and Aidit's remarks before police officers at the Police Academy in Sukabumi, in Harian Rakjat, Dec. 18, 1964. 
to determine violation of 1 aws. ${ }^{19}$ This was supported by Subandrio, ${ }^{120}$ and the country's Attorney-General, Minister Brigadier-General Sutardhio. He felt compelled to ask the country's prosecutors to solve problems in an "unconventional way."121 One example of such "revolutionary justice," where the judiciary came under the influence of mass pressures from below, was the aftermath of the so-called Bandar Betsy Affair. ${ }^{122}$ In a highly charged political atmosphere, capital politics in September 1965 witnessed the start of a political denunciation campaign. ${ }^{123}$

While these ideological and political changes were taking effect on the capital level and set a leftward trend, other, more profound changes were outlined in Sukarno's major speech of 1965. The political reorientation Sukarno charted in his Berdikari speech to the MPRS in April 1965 testifies to his inclination to integrate foreign and domestic policy. Although the Berdikari speech mainly related a plan to create a self-reliant economy with domestic capital accumulation, it contained clear references to extending the idea of self-reliance to the fields of culture, education, military defense doctrines and armament, and elsewhere. These proposals should be seen in the context of Sukarno's fear of political subversion, military intervention and Western cultural penetration, and the apprehension that $h$ is domestic opponents, especially the Army, would attempt a coup with foreign

119. Aidit's remarks before police members in Kebajoran Baru, March 10, 1965, in Antara, March 11, 1965, B; see also Aidit's address to a congress of judges, "Djadikan hukum dan hakim alat revolusi," in Harian Rakjat, April 5, 1965.

120. Address to judges from all over Indonesia, in Antara, August 24, 1965, A.

121. Address at the opening of the Third Al1-Djambi Prosecutors' Working Conference, July 17, 1965, in Antara, July 21, 1965, B.

122. On May 14, 1965, a second lieutenant of the Army, assigned to duty on a government-owned plantation at Bandar Betsy (Simelungun, North Sumatra) was clubbed to death when he tried to evict a group of peasants and youth cultivating land belonging to the plantation. In June 1965, 36 peasants were sentenced to prison terms ranging from 5 to 15 years by the Pematang Siantar district court. This triggered off a polemical newspaper debate in the country and after petitions and protests the government instructed the higher court in Medan to review the case (July 4). Members of the court were summoned to the capital, and a spokesman for the court announced that the high court would base its consideration in this case "not on pure justice alone, but also take due account of the statements and expressions, of society's sense of justice." See Antara, June 25, 1965, A; July 5, 1965, B; July 24, 1965, A; see also Indonesian Herald, July 7, 1965.

123. In September the Attorney-General appealed to the public to pinpoint economic "corruptors" to the authorities (Antara, Sept. 4, 1965, B), and the Djakarta Raya police opened its doors for 24 hours to receive reports from the public on "irresponsible" activities of "kabir" and "economic dynasty" elements (Antara, Sept. 25, 1965, B). There were also repeated proposals from government officials to shoot "big caliber manipulators" and "economic criminals" before a firing squad (Antara, Sept. 12, A-B; Sept. 27, B). For Aidit's suggestion for a "Gerakan Melapor" (reporting movement) and a system of rewards and protection for denunciators, see his speech to the political education course of Kotrar, Sept. 16, 1965, in Harian Rakjat, Sept. 17, 1965. 
political and financial backing. ${ }^{24}$

The Berdikari policy, therefore, beyond its immediate economic implications, was an attempt to isolate his domestic political opponents from their foreign imperialist and revisionist supporters. The termination of Indonesian student exchanges with the United States, the expulsion of the Peace Corps, the shutting down of USIS libraries and the offices of the Ford Foundation, and the reminder to the Army to renounce its Western military training and defense concepts--all these moves were actions against the domestic opponents of the SukarnoPKI alliance.

The Indonesian Coup and Sukarno's Politics in Perspective

In view of these domestic changes in pre-coup Indonesia, I think it can no longer be maintained that Sukarno was "balancing," that his alliance with the Army was still intact, or that he was a conservative protecting the status quo. A political change to the left was clearly apparent, and it was clearly perceived by Indonesians as such.

The difference in interpretation between the view that nothing had really changed in the conservative character of the system and its leader, and the more radical view of Sukarno and the late period of Guided Democracy derives from the following conflict in evaluating ideology and political power. The orthodox analysis stresses the "smokescreen" function of ideology, and sees no relation between ideology and political action. It also favors an assessment of the 1965 pre-coup situation which stresses the Army's monopoly of weapons to assert that the balance of power had never changed. All assessments which focus on the monopoly of weapons as the strongest indicator of political power seem to evaluate the pre-coup period with an ex post facto analytical bias. The apparent ease and swiftness with which the Communist Party was destroyed after the October 1 , 1965 , coup, the strength of the very heterogeneous coalition which participated and rejoiced in its annihilation, and the lack of resistance the party offered against its fate--ali these facts support the charges that the pre-coup political offensive of the PKI had merely been a bluff without real substance, and that supreme power had always rested with the Army.

Such an analysis fails to perceive, however, that the PKI-Sukarno strategy had probably intended to keep the political offensive below a threshold of violence in order that the Army would never have a chance to use its guns. The Army's power of physical coercion was only a potential force, restrained by the President's authority and the lack of a legitimate pretext to utilize it. The Army's real situation in early 1965 was not potential dominance in a military showdown, but rather was increasing political isolation, and--as the post-coup purges have affirmed--internal divisions and conflict with the other services. Therefore pre-coup Indonesian politics cannot be understood in terms of the drastically changed political conditions which became effective after October $1,1965$.

124. For Sukarno's fear of foreign subversion and the CIA, see note 60 above. He constantly reminded his listeners to read the following books about the CIA: Thomas B. Ross and David Wise, The Invisible Government (New York: Random House, 1964), Andrew Tully, CIA, The Inside Story (New York: Morrow, 1962), and Morris West, The Ambassador (New York: Morrow, 1965). 
The Indonesian post-coup power configuration was radically altered by the introduction of physical violence into the political contest. The Army interpreted the coup attempt as a legitimate reason to use its force. The atmosphere of political competition and the inroads of the Left in the pre-coup period were nullified by the injection of weapons into the political struggle. The struggle was now conducted at a different level and with rules which mortally disfavored the PKI and Sukarno. In such a situation the pre-coup political trend could be literally revoked overnight, and it was made possible for the uncommitted middle group of the population to determine the winner of the contest.

It cannot be denied, however, that the strength of the conservative forces had been substantial in the period of political offensive by the Left in the pre-coup months, although they were under increasing pressures to adjust to the leftist trend of politics. The coalition of anti-Communist, anti-Sukarno and anti-China forces which rallied around the Army, the Islamic groups, the non-Communist students, intellectuals and technocrats, was an impressive force, which had largely offset the leftist gains in capital politics through counteractions, evasion or a stalemate in the outer regions. It is doubtful, however, whether the conservative forces would have, in the end, succeeded in winning over the middle ground of the population to their side. If the gradual changes had continued and Sukarno's authority had remained intact, it seems questionable whether the conservatives could have resisted the trend for good. The intervention of the coup reduces this question to mere speculation, but the continued strength of Sukarno in the political system till March 1966 and the hesitation of the Army to move against him despite his tarnished image, allows one to wonder whether the Army would have dared to move against him in a time when his authority had not been compromised and it had no legitimate pretext to interfere physically in politics.

My interpretation of Sukarno--allied with the Left and the PKI, seriously committed to Nasakom as a political ideal, and in the final phase of Guided Democracy genuinely interested in the progress and radical intensification of the revolution--in short, is of a Radical rather than a Conservative. This viewpoint can be challenged from yet another perspective, which would assert that during the last stage of Guided Democracy Sukarno was no longer in full control and was used by the PKI for their own ends. Such a view sees Sukarno's alliance with the Left not as a conscious step on his part, but as a scheme of the PKI dependent on his naiveté.

It seems to me that neither the interpretation of Sukarno as a "stooge" of the PKI (which would serve a definite political function), nor the more orthodox view of Sukarno as a conservative can stand the evidence of his consistent post-coup commitment to the PKI, Nasakom unity and the interpretation of the Indonesian Revolution as a leftist revolution. When, in the judgment of many observers, he could have retained his position if he had sacrificed the PKI and his insistence on the revolution as a leftist one, he stubbornly defended both at the price of his own demise. ${ }^{125}$ It has been said that prinzipientreue was

125. See Sukamo's post-coup speeches as published in the Penerbitan Chusus series of the Information Department: especially Binalah Kesatuan dan Persatuan Nasional Progresif Revolusioner atas Dasar Pantja Azimat Revolusi (Oct. 23, 1965, P.C. No. 388); Marilah Kita bersama-sama menjelamatkan Revolusi kita (Oct. 27, 1965, 
one of Sukarno's outstanding characteristics: His commitment to the progressive-leftist character of the Indonesian Revolution was his last, highly principled decision. In very emotional speeches after the coup, he tried to stem the tide of reaction and murder sweeping the country. He defended the PKI and reminded his audiences repeatedly that the party had made many more sacrifices for Indonesian independence and the revolution than any other group, even his own nationalist group. ${ }^{26}$ He warned his countrymen that their eagerness to eliminate the PKI irrevocably shifted the Indonesian Revolution to the right.127 He may have already comprehended that those forces responsible for the anti-PKI program were intent on completely transforming his vision of the Indonesian Revolution. Rather than become a puppet of the counterrevolution, he went down with his principles.

P.C. No. 389); Semua Golongan diminta agar tenang, Djangan membakar satu-samalain! (Nov. 6, 1965, P.C. No. 391); Kalau tidak kiri, bukan Revolusi Indonesia (Nov. 10, 1965, P.C. No. 393).

126. See his speech to the Bamunas (National Consultative Council of Private Enterprise) on February 21, 1966, Djakarta Domestic Service, Feb. 23, 1966.

127. See Sukarno's speech to the MPRS leadership in the Palace on December 6, 1965, Bangsa Indonesia djangan sampai merobek-robek dirinja sendiri! ([Djakarta]: Departemen Penerangan R.I., Penerbitan Chusus No. 395, [1965]), p. 10, for a metaphor which he repeatedly used after the coup. He compared the situation in the country with the activity of people who want to catch a mouse and in the process burn down a whole house. But he made it perfectly clear that he was not willing to join in arson against the house, the "house" of the Indonesian Revolution: "And this is what happened, brothers; the danger of people wanting to punish the mice by burning our house. Well, if that is the case, brothers, I say frankly, without disguise, I refuse to join in burning our house, because I personally, together with others for more than forty years, have contributed everything I have for this house." 